Historic, archived document

Do not assume content reflects current scientific knowledge, policies, or practices. 



\section{.035 \\ C 2 lited States \\ Agriculture}

Forest

Service

North Central

Forest Experiment

Station

Resource Bulletin NC-181

軨

\section{The Forest Resources of the Huron-Manistee National Forests, 1993}

David Haugen, Rosalie Ingram, and Forrest Ruppert

$$
\begin{aligned}
& \text { 焉 }
\end{aligned}
$$

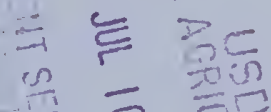

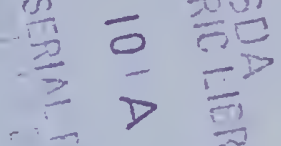

$$
\begin{aligned}
& - \\
& \text { E }
\end{aligned}
$$

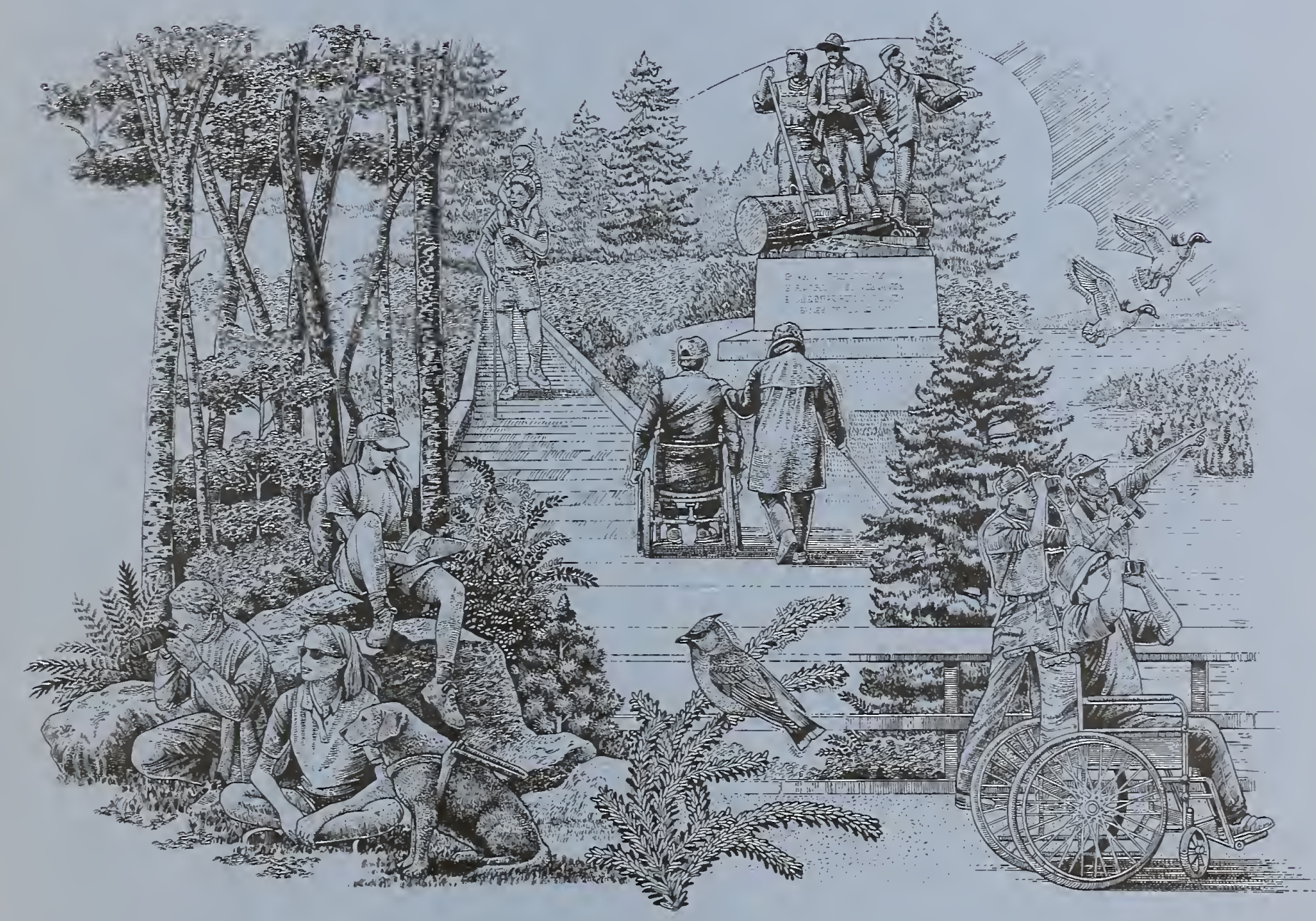


North Central Forest Experiment Station

Forest Service-U.S. Department of Agriculture

1992 Folwell Avenue

St. Paul, Minnesota 55108

Manuscript approved for publication April 24, 1997

1997 
This report includes the most commonly used U.S. Department of Agriculture, Forest Service, Inventory and Analysis (FLA) statistics. Additional forest resource data can be provided to interested users. Persons requesting additional information from the raw inventory data are expected to pay the retrieval costs. These costs range from less than $\$ 100$ for a relatively simple request to more than $\$ 2,000$ for a complex retrieval involving the services of a Forest Inventory and Analysis computer programmer. Requests will be filled so as to minimize the impact on the Forest Inventory and Analysis work unit. Interested users can also access the forest resource (FIA) data base on the Internet @ http:// www.ncfes.umn.edu/units/4801/.

Requests for information may be directed to:

Program Manager

Forest Inventory and Analysis

North Central Forest Experiment Station

1992 Folwell Avenue

St. Paul, Minnesota 55108

Phone: (612) 649-5139

or

Forest Supervisor

Huron-Manistee National Forests

421 South Mitchell Street

Cadillac, Michigan 49601

Phone: (616) 775-5023 
Extent of Forest Land on the Huron-Manistee National Forests .........2 2

Composition of the Huron-Manistee's Forests ................................ 3

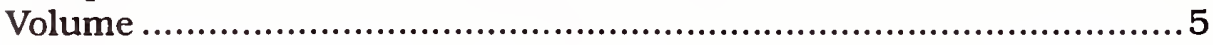

Causes of Change in the Huron-Manistee's Forest Resources ........... 5

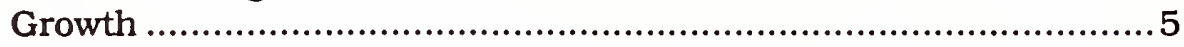

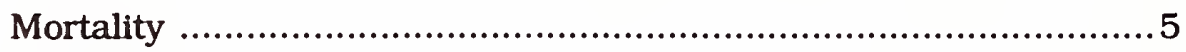

Removals ..................................................................... 5

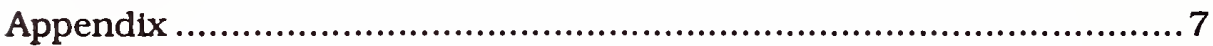

Accuracy of the Survey ......................................................

Survey Procedures ............................................................... 8

Major Steps in the New Survey Design ..................................9

Tree and Log Grade ............................................................. 11

Metric Equivalents of Units Used in This Report ....................... 16

Tree Species in the Huron-Manistee National Forests ................. 16

Definition of Terms ......................................................... 16

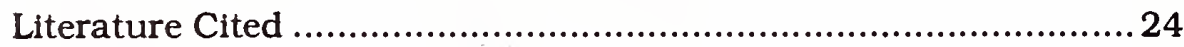

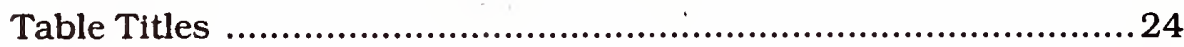

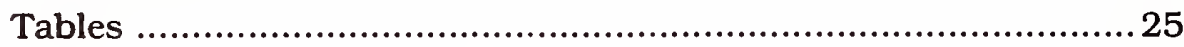




\title{
The Forest Resources of the Huron-Manistee National Forests, 1993
}

\author{
David Haugen, Rosalie Ingram, and Forrest Ruppert
}

The Huron-Manistee National Forests are centrally located in the northern Lower Peninsula of Michigan and extend from Lake Michigan to Lake Huron (fig. 1). Although they are administered jointly, the Huron and Manistee are actually two separate National Forests. The Huron, on the eastern side of Michigan, was established in 1909 from public domain lands (lands that had never been transferred to private owners). The Manistee, in western Michigan, was officially established in 1938 from tax-forfeited lands and purchases. Both National Forests are a mosaic of lands held by public and private owners.

Both Forests are underlain by sedimentary rocks, covered by a mantle of glacial drift as much as 1,000 feet thick. Glacial moraines, outwash plains, deltas, lacustrine deposits, and old shorelines are common. Soils originating from these landscapes are predominately sand. Aquifers within glacial deposits are common and feed thousands of miles of cold water streams at a relatively constant rate throughout the year. The Huron-Manistee Forests' logo, "United by Rivers," reflects the importance of the Pine, Manistee, Pere Marquette, Muskegon, and Au Sable Rivers, and their respective watersheds to forest management within the area.

Earliest known archeological sites in the area date back to the recession of the last glacier,

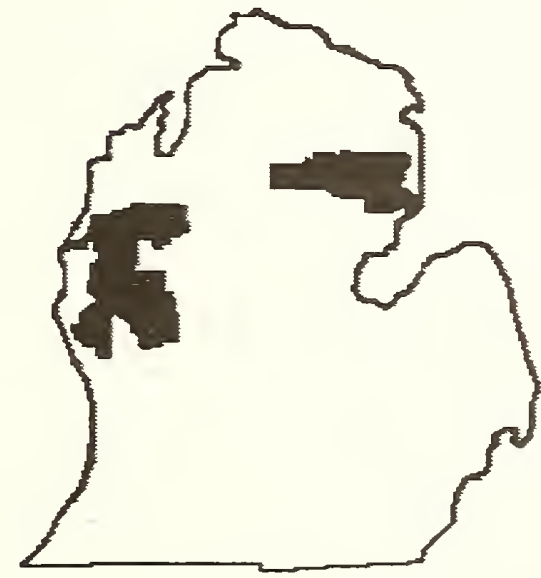

Figure 1.- Location of the Huron-Manistee National Forests in the Lower Peninsula of Michigan.

approximately 12,000 years ago. More than 1,000 cultural resource sites have been recorded on the Forests. These sites represent the cultures of many peoples, from PaleoIndian hunters to European explorers and settlers.

European occupancy began in the early 1600's with French and English fur trappers. In the early 1800's, the first settlers began to arrive in the area. Soon after, limited logging began near settlements along the Au Sable river. But it was not until the 1850's and 1860's that logging and sawmilling reached their highest
David Haugen is a Forestry Technician in the Forest Inventory and Analysis Unit at the North Central Forest Experiment Station, St. Paul, Minnesota. He received a bachelor's degree in forest management from the University of Minnesota. He joined the Forest Service in 1990 and worked for Northeastern Area State and Private Forestry before joining the FIA staff.

Rosalie Ingram is a Forest Silviculturist and Recreation Program Manager for the HuronManistee National Forests. She received a bachelor's degree in forestry from Michigan State University. She joined the Forest Service in 1977 and has worked at the North Central Forest Experiment Station (East Lansing); the Targhee, Umpqua, and Mark Twain National Forests; and in the Regional Office in Region 9.

Forrest Ruppert is a Forest Silviculturist in the Timber Management Program of the Huron-Manistee National Forests. He received a bachelor's degree in forestry from Michigan State University. He joined the Forest Service in 1968 and has worked on the Ottawa, Tongass, and Chugach National Forests and with State and Private Forestry at Fairbanks, Alaska. 
levels with the commercial harvest of red and white pine. After the peak years, logging continued on a smaller scale in hardwood and scattered pine stands. Attempts to farm the cutover forest lands suceeded only on the better soils. By the 1930's, many burned-over forest lands had still not regenerated to trees. Fire control in the 1930's allowed renewed natural regeneration, and the large tree planting programs during the Civilian Conservation Corps era helped create the forest landscapes we see today across the National Forests.

Today, the Huron-Manistee National Forests provide a wealth of products and services. The Forests are within a day's drive of nearly 50 million people. Increased leisure time and better highway access allow ever increasing numbers of people to "discover" the National Forests and their varied resources through shorter but more frequent visits. In addition, the forest products industry in and around the Huron-Manistee has contributed greatly to the local and regional economies as well as to the lifestyles of residents in the northern Lower Peninsula. The high timber sale revenues of the Huron-Manistee over the last several years mirror the increasing tree size, greater sawtimber and growing-stock volumes, and higher quality estimated in the fifth and most recent inventory of Michigan's forest resources. The Huron-Manistee National Forests also contain regionally and locally unique ecosystems that several endangered species and others depend on (fig. 2). Examples are the Kirtland's warbler, with its specific breeding range on the Huron National Forest and adjoining State lands; and the Karner blue butterfly, found in large numbers on the southern Manistee National Forest.

Managing for such diverse products and services is growing increasingly complex. Tradeoffs between resources, economic sustainability and public policy guide forest land managers in public land management, planning, and implementation. In the meantime, the Forest Service's commitment to ecosystem management on the HuronManistee and other National Forests could result in changes in management direction. This analysis of the forest resources of the Huron-Manistee National Forests, along with previous and future inventories, will give us a much clearer picture of how forest resources are affected by such changes.

\section{EXTENT OF FOREST LAND ON THE HURON-MANISTEE NATIONAL FORESTS}

Of the 964,900 total acres of Huron-Manistee National Forests lands, 951,100 acres are forested-an increase of 5 percent between 1980 and 1993. The remaining acres consist

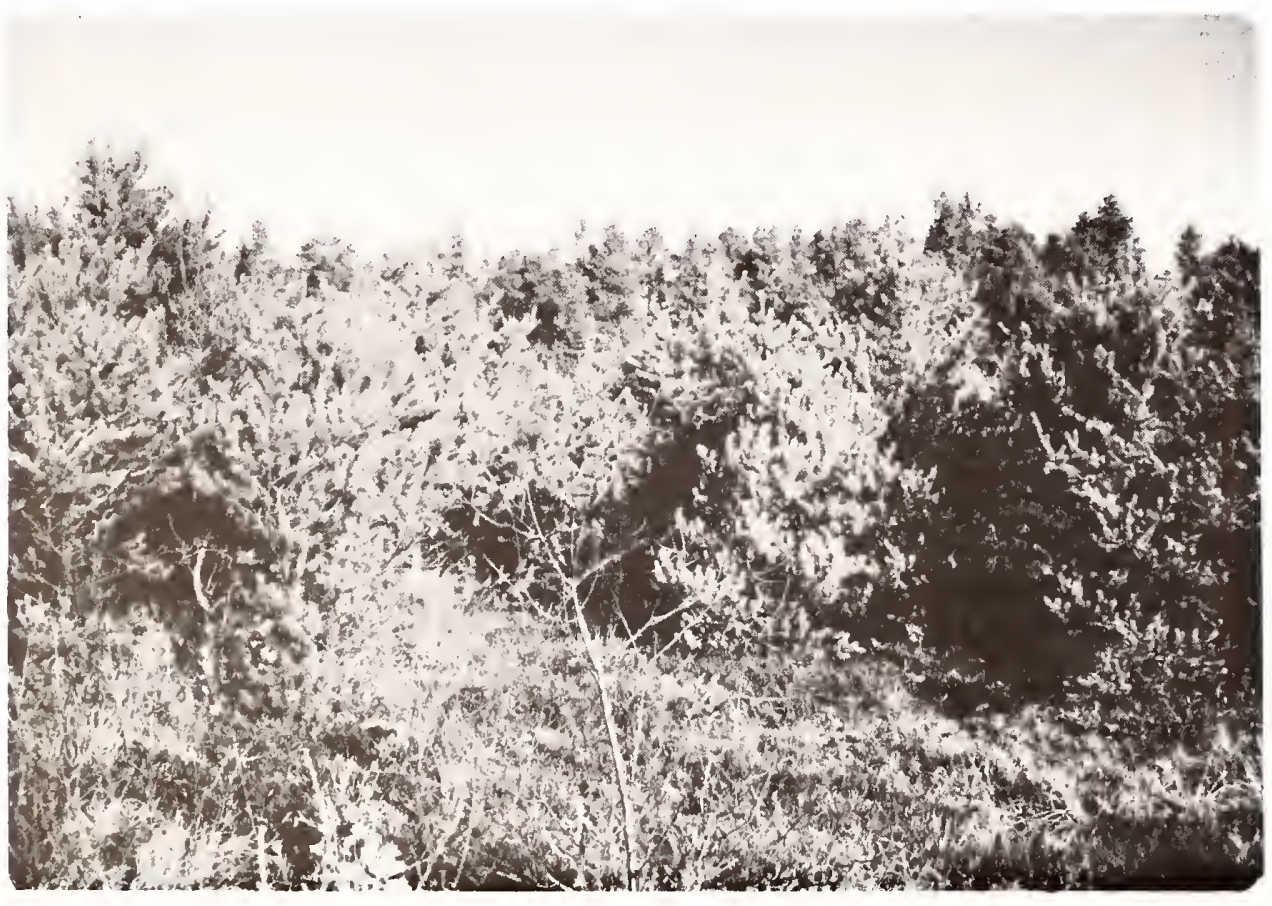

Figure 2.-Kirtland's warbler habitat, a young jack pine stand on the Huron National Forest. 
of natural open areas such as wetlands and developed land such as roads and rights-ofway. The Huron-Manistee forest land area $(949,300$ acres) has the potential to annually produce 20 or more cubic feet of wood per acre. The Huron-Manistee forest land area can be divided into timberland $(915,100$ acres), reserved timberland (34,200 acres), and other forest land (1,800 acres).

In 1993, 13 different forest types were inventoried on the Forests compared to 10 in 1980. Conifer forest types occupied 359,100 acres in 1993, up from 339,000 acres in 1980 . Hardwood forest types increased from 528,500 acres in 1980 to 556,000 acres in 1993. For example, the aspen forest type decreased while the maple-beech-birch forest type increased (fig. 3). Jack pine forest type decreased, but red and white pine forest types increased. Many of the changes can be attributed to forest succession. As forests mature, early successional species like aspen fall out of dominance and mid-to-late successional species like maple fill in. Other changes may be attributed to silvicultural and wildlife management practices such as habitat management for the Kirtland's warbler.

\section{COMPOSITION OF THE HURON-MANISTEE'S FORESTS}

The Huron-Manistee National Forests have a great variety of tree species, which can be attributed to many factors including varied forest soil types, geological formations, climate, hydrological conditions, fauna, and disturbance (fig. 3). In 1980, the two Forests had an estimated 508 million trees at least 1 inch in diameter at breast height (d.b.h.); by 1993, the number of trees had increased to 548 million. The most prevalent conifer tree species recorded during the 1993 inventory was red pine, with 81 million trees. Other conifer species found in abundance in 1993 included jack pine, white pine, balsam fir, and northern white-cedar (fig. 4).

The soft maple species, with 71 million trees, replaced aspen as the most abundant hardwood during the 1993 inventory. Other hardwood species found in abundance include aspen, red oak, white oak, hard maple, and black cherry (fig. 5).

One way to look at the forest resource is by observing stand-size class. This classification of forest land recognizes three size classes based on the average d.b.h. of the predominant

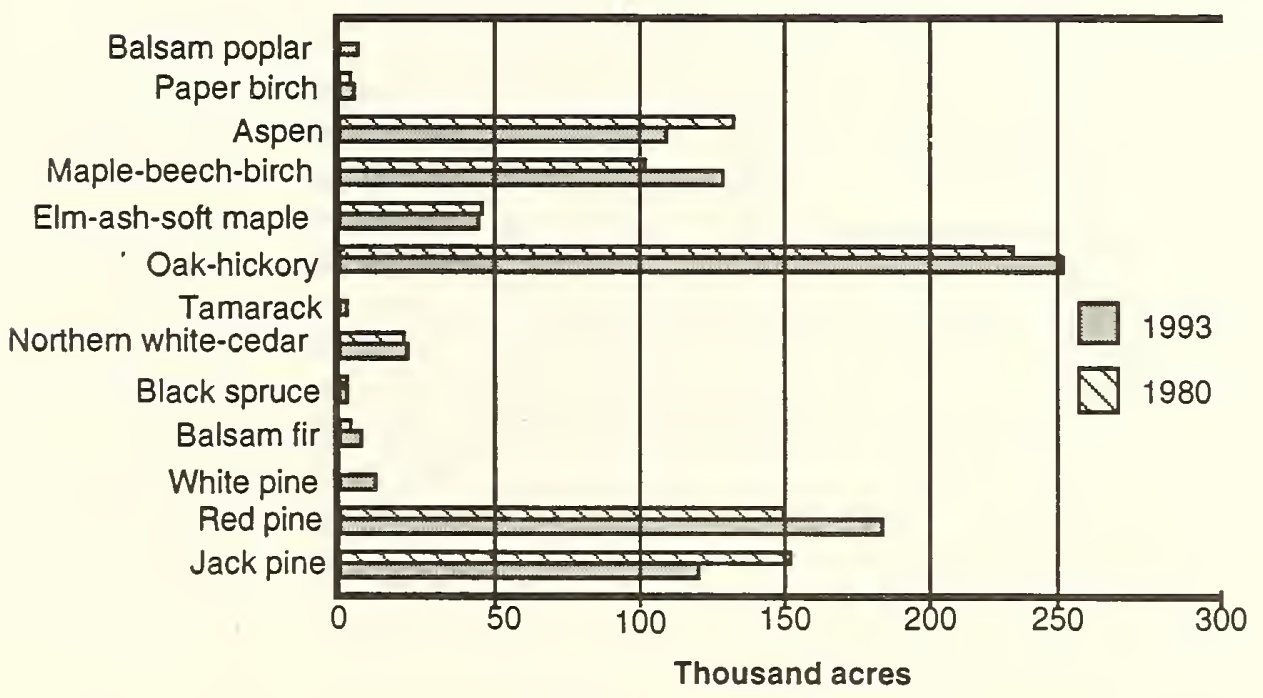

Figure 3.-Area of timberland by forest type on the Huron-Manistee National Forests, 1980 and 1993. 


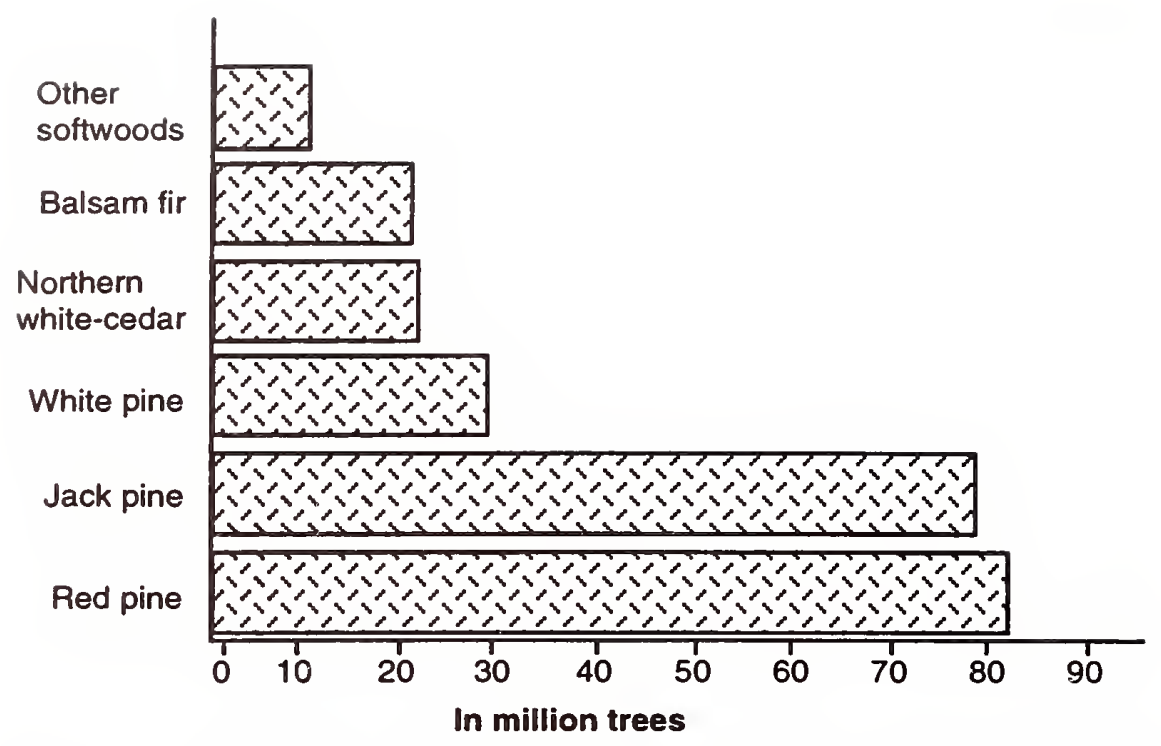

Figure 4.-Number of conifer trees on timberland on the Huron-Manistee National Forests, 1993.

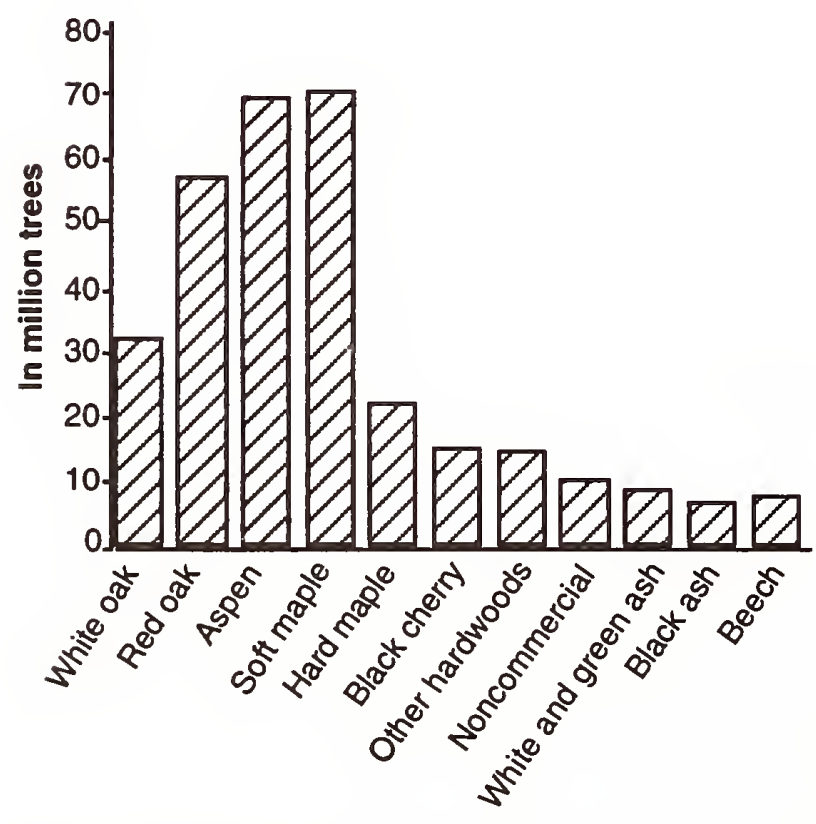

Figure 5.-Number of hardwood trees on timberland on the Huron-Manistee National Forests, 1993. trees within the stand: sapling/seedling (trees between 1 and 5 inches d.b.h.); poletimber (trees 5 to 9 inches d.b.h. for conifers and 5 to 11 inches d.b.h. for hardwoods); and sawtimber (trees more than 9 inches d.b.h. for conifers and more than 11 inches d.b.h. for hardwoods). Between inventories, two stand-size classes decreased in area and one increased (fig. 6). Sapling/seedling stands decreased from 262 thousand acres in 1980 to 194 thousand acres in 1993, a 26-percent decline. Poletimber stand area declined from 470 thousand acres in 1980 to 390 thousand acres in 1993, a 17-percent decrease. Sawtimber increased by 144 percent between inventories, from 135 thousand acres in 1980 , to 330 thousand acres in 1993. Forest types with the biggest gains in the sawtimber size-class include red pine, oak-hickory, maple-beechbirch, and aspen. In the sapling/seedling sizeclass, many forest types decreased; aspen declined the most, with red pine a close second. In the poletimber size-class, four forest types decreased in area: jack pine, oakhickory, elm-ash-soft maple, and paper birch. 


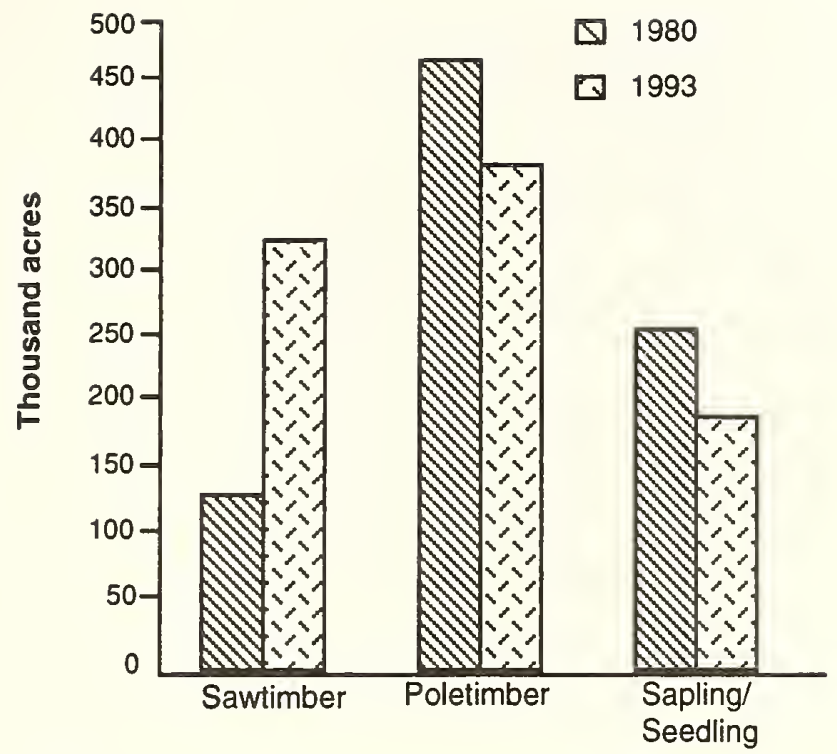

Figure 6.-Area of timberland in 1980 and 1993 on the Huron-Manistee National Forests by stand-size class.

\section{VOLUME}

The net growing-stock volume on the HuronManistee National Forests grew from 807 million cubic feet in 1980 to 1.2 billion cubic feet in 1993-an increase of 49 percent. Between inventories, jack pine, balsam fir, yellow birch, elm, and black ash decreased in growing-stock volume, while all other species groups increased. Of all tree species white pine made the greatest gains between inventories. White pine growing-stock volume increased by 180 percent between inventoriesfrom 15 million cubic feet in 1980 to 42 million cubic feet in 1993. Net volume for white pine sawtimber increased from 1.4 billion board feet in 1980 to more than 3 billion board feet in 1993-an increase of 117 percent. Red pine, jack pine, white pine, and northern white-cedar made up 96 percent of the total net volume of softwood on the Forests in 1993. Likewise, red and white oak, hard and soft maple, and aspen made up 89 percent of the total hardwood volume on the Forests. Only elm, yellow birch, and balsam poplar decreased in net volume of sawtimber between inventories.

\section{CAUSES OF CHANGE IN THE HURON- MANISTEE'S FOREST RESOURCES}

\section{Growth}

On the Huron-Manistee National Forests, average net annual growth of growing stock was 39.5 million cubic feet per year between 1980 and 1993 (fig. 7). Both conifer and hardwood species averaged more than 19 million cubic feet per year in net annual growth of growing stock (fig. 8). On a per acre basis, the Forests averaged 43 cubic feet per year in net annual growth between inventories, compared to the State average of 41 cubic feet per year. Red pine accounted for 39 percent of all net annual growth of growing stock on the Forests, while select white oak, select red oak, soft maple, and aspen each averaged more than 10 percent of the total growing-stock growth.

Net annual growth of sawtimber on the Forests averaged 134.4 million board feet per year between inventories, an average of 146 board feet per acre per year (the overall State average was 143 board feet per acre per year). Red pine represented 35 percent, select red oak represented 15 percent, and aspen represented 8 percent of the total net average annual sawtimber growth.

\section{Mortality}

Between inventories, average annual mortality on the Forests was 6.7 million cubic feet for growing-stock trees and 11.6 million board feet for sawtimber-size trees (fig. 7). The causes of mortality included diseases such as hypoxylon canker, Dutch elm, verticillium wilt, and white trunk rot; insects such as jack pine budworm, gypsy moth, and ips beetle; animals such as deer and porcupine; and weatherrelated factors such as damaging winds, flooding, and drought.

\section{Removals}

Annual timber removals averaged 14.5 million cubic feet of growing stock and 25.9 million board feet of sawtimber per year between inventories (fig. 9). Both growing-stock and sawtimber removals exceeded mortality by a two to one margin. Removals of red, jack and white pine; red and white oak; soft maple; and aspen species groups accounted for 87 percent of the growing-stock removals and 91 percent of sawtimber removals on the Forests. 

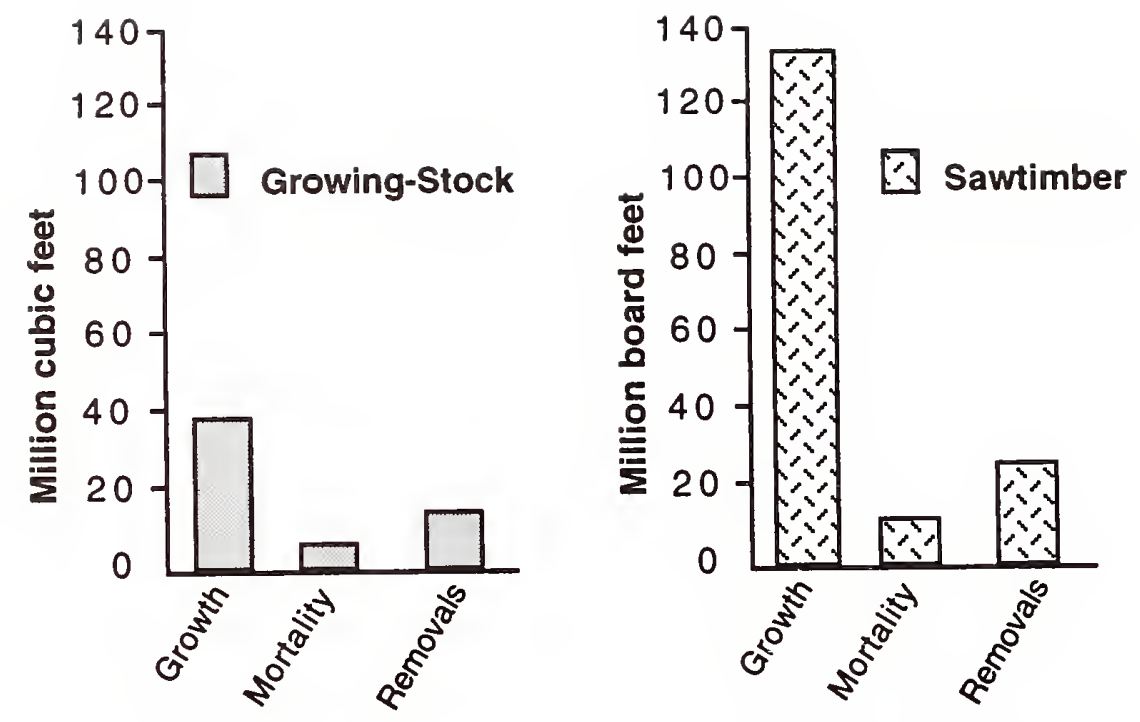

Figure 7.-Average net annual growth, average annual mortality, and average annual removals of growing stock and sawtimber on timberland on the Huron-Manistee National Forests, 1980-1993.
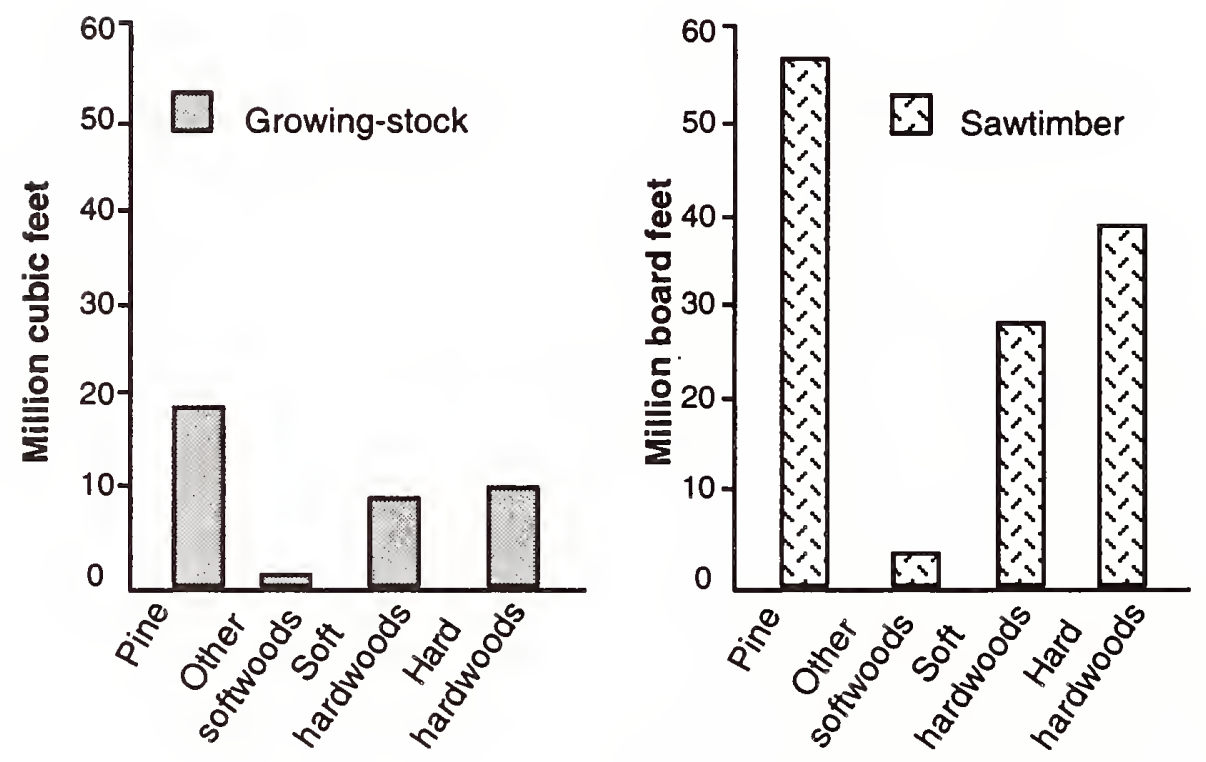

Figure 8.-Average net annual growth of growing stock and sawtimber on timberland by major species group, Huron-Manistee National Forests, 1980-1993. 

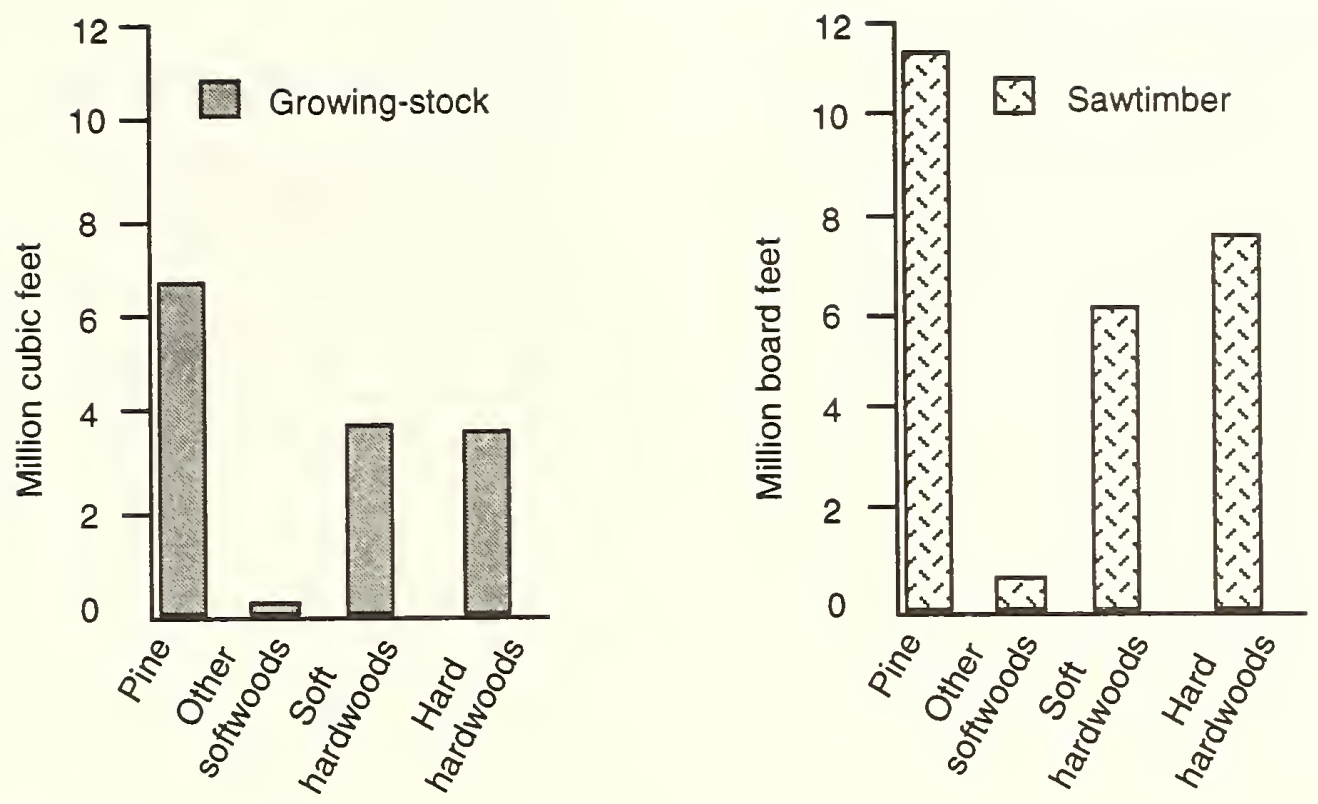

Figure 9.-Average annual removals of growing stock and sawtimber on timberland by major species group. Huron-Manistee National Forests, 1980-1993.

\section{APPENDLX}

\section{ACCURACY OF THE SURVEY}

Forest Inventory and Analysis information is based on a sampling procedure designed to provide reliable statistics at the State and Survey Unit levels. Consequently, the reported figures are estimates only. A measure of reliability of these figures is given by sampling errors. These sampling errors mean that the chances are two out of three that if a 100percent inventory had been taken, using the same methods, the results would have been within the limits indicated. For example, the

\section{Item}

Growing stock

Volume (1993)

Average annual growth

(1980-1992)

Average annual removals

(1980-1992)

Sawtimber

Volume (1993)

Average annual growth

(1980-1992)

Average annual removals

(1980-1992)

Timberland area (1993)

estimated growing-stock volume in the HuronManistee National Forests in 1993, 1,242.4 million cubic feet, has a sampling error of \pm 3.70 percent $( \pm 45.9$ million cubic feet). The growing-stock volume from a 100 -percent inventory would be expected to fail between 1,288.3 and $1,196.5$ million cubic feet $(1,242.4 \pm 45.9)$, there being a one in three chance that this is not the case.

The following tabulation shows the sampling errors for the inventory of the Huron-Manistee Nationail Forests:

Forest totals

Million cubic feet

$1,242.4$

39.5

14.5

Million board feet

3.037 .7

134.4

25.9

Thousand acres

915.1

\section{Sampling error}

Percent

3.70

4.90

13.70

5.10

5.30

16.20

1.20 
As survey data are broken down into sections smaller than Survey Unit totals, the sampling error increases. For example, the sampling error for timberland area in a particular county is higher than that for total timberland area in the Unit. To estimate sampling error for data smaller than Unit totals, use the following formula:

$$
\mathrm{E}=\frac{(\mathrm{SE}) \sqrt{(\text { Forest total volume or area })}}{\sqrt{(\text { Volume or area smaller than Forest total })}}
$$

Where :

$\mathrm{E}=$ Sampling error in percent.

$\mathrm{SE}=$ Forest total error for volume or area.

For example, to compute the error on the area of timberland in the maple-beech-birch type for the Huron-Manistee, proceed as follows:

1) The total area of maple-beech-birch type from table $3=133,100$ acres.

2) The total area of all timberland in the Huron-Manistee National Forests from table $3=915,100$ acres.

3) Total error for timberland area from the above tabulation $=1.20$ percent .

4) Using the above formula:

$$
\mathrm{E}=\frac{0.0120 \sqrt{915,100}}{\sqrt{133,100}}
$$

$E=0.0310$ or 3.1 percent - sampling error for the maple-beech-birch forest type in the Huron-Manistee National Forests.

\section{SURVEY PROCEDURES}

The 1993 Huron-Manistee survey used a growth model-enhanced, two-phase sample design. Using this sampling scheme and associated estimators is similar to sampling with partial replacement (SPR), in that a set of randomly located plots is available for remeasurement and a random set of new plots is established and measured. A significant feature of the design is stratification for disturbance on the old sample and use of a growth model to improve regression estimates made on old undisturbed forest plots (fig. 10). Detailed descriptions of the sampling and estimation procedures are presented by Hansen (1990). The growth model used in the Michigan survey design was the Lake States Stand and Tree Evaluation and Modeling System (STEMS) (Belcher et al.1982).

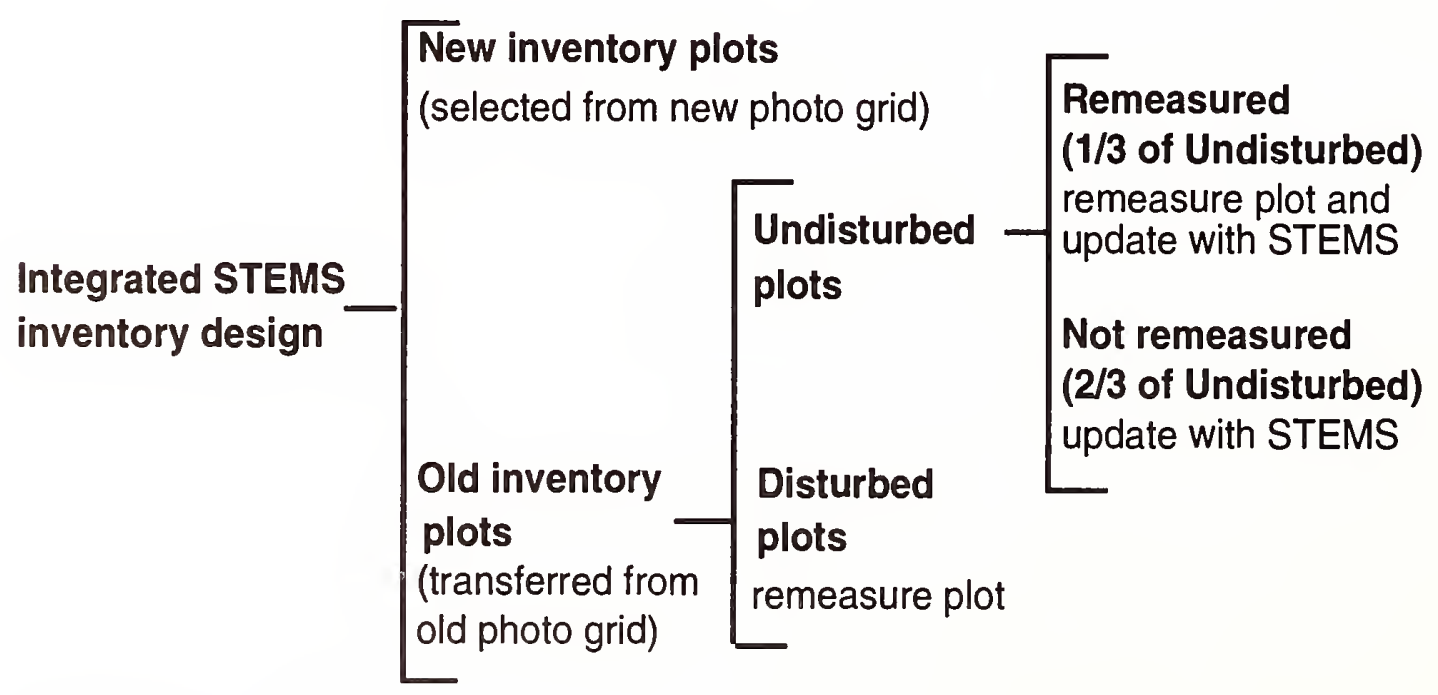

Figure 10.-- Overview of the sample design for the Huron-Manistee National Forests survey. 


\section{Major Steps in the New Survey Design}

\section{Aerial photography (Phase 1)}

In this phase, two sets of random points were located on current aerial photography. The first is a set of new photo plots, and the second is a set of relocated old ground plot locations from the 1980 inventory. Aerial photographs used were black and white, infrared taken in 1986 at a scale of $1: 15,840$ (nominal). These photographs were purchased by the Michigan Department of Natural Resources (MiDNR) and loaned to the Forest Service. The locations of the plots used in the 1980 inventory were transferred to these new photographs. The photographs were then assembled into township mosaics, and a systematic grid of 121 oneacre photo plots (each plot representing approximately 190.4 acres) was overlaid on each township mosaic. Each of these photo plots was examined by aerial photo interpretation specialists and classified stereoscopically based on land use. If trees were present, forest type and stand-size/density class were recorded. After this examination, all the old "disturbed" sample locations and one-third of the old "undisturbed" forested plots were sent to the field for survey crews to verify the photo classification and to take further measurements. All photo plot locations for the 1993 inventory were examined and were classified as shown in the following tabulation.

\begin{tabular}{lr}
\hline Photo land class & Photo plots \\
\hline Timberland & 4,823 \\
Reserved forest land & 81 \\
Other forest land & 0 \\
Questionable forest & 41 \\
Nonforest with trees & 10 \\
Nonforest reserved & 0 \\
Nonforest without trees & 163 \\
Water & 0 \\
All classes & 5,118 \\
\hline
\end{tabular}

\section{Plot measurements (Phase 2)}

On plots classified as timberland, wooded pasture, or windbreak (at least 120 feet wide), a ground plot was established, remeasured, or modeled. Old plots that could not be relocated were replaced with a new plot at the approximate location of the old one. Each ground plot consisted of a 10-point cluster covering approximately 1 acre. At each point, trees 5.0 inches or more in d.b.h. were sampled on a 37.5 Basal Area Factor (BAF) variable-radius plot, and trees less than 5.0 inches d.b.h. were sampled on a 1/300-acre fixed-radius plot. The measurement procedure for the new and old sample locations were as follows:

\section{a) New inventory plots}

A systematic sample of the new photo plots was selected for field measurement. Ground plots were established, and measures of current classification such as land use, forest type, and ownership as well as size and condition of all trees on the plot were recorded. These locations were monumented for future remeasurement.

\section{b) Old inventory plots}

These plots were established, monumented, and measured as part of the 1980 field inventory. The procedures for these old plots were different from those for the new plots. Old plots were classed as "undisturbed" or "disturbed" in the aerial photo phase of the sampling process. All disturbed plots and a onethird sample of the undisturbed plots were remeasured to obtain estimates of current condition and changes since the last inventory. All trees measured on these plots in 1980 were remeasured or otherwise accounted for, and all new trees were identified and measured.

All sample plots that were forested at the time of the 1980 inventory and determined to be undisturbed until this inventory were projected to the current time using STEMS. This procedure gives projected estimates of current volume and growth for these undisturbed plots. The comparison of the projected and 
observed values on the one-third sample of the undisturbed forest plots that were remeasured provided local calibration data to adjust the projected values of the undisturbed plots that were not remeasured. The adjustment procedure is a modified version of the method described by Smith (1983).

The undisturbed forested plots that were not remeasured play a crucial role in the new survey design. These plots, after careful examination comparing past and current aerial photography, were determined to be undisturbed and had conditions that could be simulated by STEMS. The STEMS growth model was used to "grow" the old plot and tree data to produce an estimate of current data. Thus, these plots were treated as ground plots, even though they were never visited. The plot record for each modeled plot was sent to the field for verification of current ownership information.

All old plots classified as disturbed were sent to the field for remeasurement to assess and verify changes since the last inventory. Disturbance refers to any change on a plot that can be detected on aerial photos and that the STEMS growth processor cannot predict, such as catastrophic mortality, cutting, seedling stands, and land use change.

The estimation procedure for computing statistics from this sampling design was more complicated than the simple two-phase estimation procedure used in the past. In fact, this procedure yielded two independent samples, one coming from the new photo points and the other from the old photo points that are remeasured or modeled. The following tabulation summarizes the distribution of all ground plots for the new inventory design by type of plot:

\section{Area estimates}

Area estimates were made using two-phase estimation methods. In this type of estimation, a preliminary estimate of area by land use is made from the aerial photographs (Phase 1) and corrected by the plot measurements (Phase 2). A complete description of this estimation method is presented by Loetsch and Haller (1964).

\section{Volume estimates}

Estimates of volume per acre were made from the trees measured or modeled on the 10point plots. Estimates of volume per acre were multiplied by the area estimates to obtain estimates of total volume. Net cubic foot volumes are based on a modification of the method presented by Hahn (1984) for use in the Lake States. For the Huron-Manistee National Forests inventory, the merchantable height equation presented in Hahn (1984) was used in conjunction with Stone's equation (see Appendix 1 in Hahn, 1984) to estimate gross volume. This estimate was then corrected by species for variation in bark and cull volume to yield an estimate of net volume, using the coefficients presented in Hahn (1984).

The Forest Service reports all board foot volume in International 1/4-inch rule. In Michigan, the Scribner log rule is commonly used. Scribner log rule conversion factors were derived from full tree measurements taken throughout the Lake States (Michigan, Wisconsin, and Minnesota) and an equation developed by Wiant and Castenaeda (1977). The factors (multipliers) used to convert board foot International volumes to the Scribner rule are shown in the tabulation on the next page.

\begin{tabular}{lcccc}
\hline $\begin{array}{l}\text { Ground land } \\
\text { use class }\end{array}$ & $\begin{array}{c}\text { Old plots } \\
\text { remeasured }\end{array}$ & $\begin{array}{c}\text { Old plots } \\
\text { updated }\end{array}$ & $\begin{array}{c}\text { New } \\
\text { plots }\end{array}$ & $\begin{array}{c}\text { Total } \\
\text { plots }\end{array}$ \\
\hline $\begin{array}{l}\text { Timberland } \\
\begin{array}{l}\text { Reserved } \\
\text { forest land }\end{array}\end{array}$ & 300 & 13 & 128 & 441 \\
$\begin{array}{l}\text { Nonforest } \\
\text { with trees }\end{array}$ & 8 & 0 & 17 & 25 \\
$\begin{array}{c}\text { Nonforest } \\
\text { without trees }\end{array}$ & 1 & 0 & 1 & 4 \\
$\begin{array}{l}\text { Noncensus water } \\
\text { Total }\end{array}$ & 1 & 0 & 2 & 3 \\
\hline
\end{tabular}




\begin{tabular}{lcc}
\hline $\begin{array}{c}\text { D.b.h. } \\
\text { (inches) }\end{array}$ & \multicolumn{2}{c}{ Scribner rule conversion factor } \\
\cline { 2 - 3 } Softwoods & Hardwoods \\
\hline $9.0-10.9$ & 0.7830 & - \\
$11.0-12.9$ & 0.8287 & 0.8317 \\
$13.0-14.9$ & 0.8577 & 0.8611 \\
$15.0-16.9$ & 0.8784 & 0.8827 \\
$17.0-18.9$ & 0.8945 & 0.8999 \\
$19.0-20.9$ & 0.9079 & 0.9132 \\
$21.0-22.9$ & 0.9168 & 0.9239 \\
$23.0-24.9$ & 0.9240 & 0.9325 \\
$25.0-26.9$ & 0.9299 & 0.9396 \\
$27.0-28.9$ & 0.9321 & 0.9454 \\
$29.0+$ & 0.9357 & 0.9544 \\
\hline
\end{tabular}

5. Growth and mortality estimates

On remeasured plots, estimates of growth and mortality per acre come from the remeasured diameters of trees and from observation of trees that died between inventories. Growth reported as the average net annual growth between the two inventories (1980 and 1993) is computed from data on remeasurement plots and modeled plots using methods presented by Van Deusen et al. (1986). Mortality is also average net annual for the remeasurement period. On new plots, where trees were not remeasured, estimates of growth and mortality were obtained by using STEMS to project the growth and mortality of trees for 1 year. Growth and mortality estimates for old undisturbed plots that were updated were derived in the same manner as remeasured plots. The STEMS growth model was adjusted by Survey Unit to meet local conditions, using data from the undisturbed remeasurement plots. As with volume, total growth and mortality estimates were obtained by multiplying the per acre estimates by area estimates. Current annual growth for 1992 was computed by using the adjusted STEMS model to grow all current inventory plots for 1 year.

\section{Average annual removals estimates}

Average annual growing-stock and sawtimber removals (1980 to 1992) were estimated only from the remeasured plots; new plots and STEMS-projected plots were not used to estimate removals. These estimates are obtained from trees measured in the last survey and cut or otherwise removed from the timberland base. Because remeasurement plots make up about one-half of the total ground plots, average annual removals estimates have greater sampling errors than volume and growth estimates.

\section{Tree and Log Grade}

Log grades and tree grades are based on the classification of external characteristics as indicators of quality. Log grades and or tree grades were taken on approximately one-third of the sample plots in the Huron-Manistee National Forests. All sawtimber softwood sample trees were graded for quality and assigned a butt log grade. All sawtimber hardwood sample trees were graded for quality and assigned a tree grade. The volume yield by log grade or tree grade for this sample was used to distribute the volume of the ungraded sample trees by species group.

Hardwood sawtimber trees were graded according to "Hardwood tree grades for factory lumber" (Hanks 1976). The best 12-foot section of the lowest 16-foot hardwood log was used for grading. Hardwood sawtimber trees that did not meet minimum tree grade specifications for grades 1 through 3 were assigned grade 4 according to Forest Service standard specifications for hardwood construction logs described in "A Guide to Hardwood Log Grading” (Rast et al. 1973).

Red pine and jack pine sawtimber trees were graded based on specifications described in "Forest Service Log Grades for Southern Pines" (Campbell 1964). White pine and other softwood sawtimber trees were graded according to specifications described by Ostrander and Brisbin (1971). For all softwoods, the first merchantable 16-foot log, or shorter lengths down to 12 feet, was used for grading. 
Hardwood Tree Grade for Factory Lumber a

\begin{tabular}{|c|c|c|c|}
\hline Grade factor & Tree grade 1 & Tree grade 2 & Tree grade 3 \\
\hline Length of grading zone (feet) & Butt 16 & Butt 16 & Butt 16 \\
\hline Length of grading section $b$ (feet) & Best 12 & Best 12 & Best 12 \\
\hline D.b.h., minimum (inches) & $16^{\mathrm{c}}$ & 13 & 11 \\
\hline $\begin{array}{l}\text { D.i.b., minimum at top of grading } \\
\text { section (inches) }\end{array}$ & $13^{\mathrm{c}} 16 \quad 20$ & $11^{\mathrm{d}} \quad 12$ & 8 \\
\hline $\begin{array}{l}\text { Clear cuttings (on the } 3 \text { best faces) } \\
\text { Length, minimum (feet) } \\
\text { Number on face (maximum) } \\
\text { Yield in face length (minimum) }\end{array}$ & $\begin{array}{ccc}7 & 5 & 3 \\
& 2 & \\
& 5 / 6 & \\
\end{array}$ & $\begin{array}{lr}3 & 3 \\
2 & 3 \\
4 / 6 & \end{array}$ & $\begin{array}{c}2 \\
\text { Unlimited } \\
3 / 6\end{array}$ \\
\hline $\begin{array}{l}\text { Cull deduction (including crook and } \\
\text { sweep, but excluding shake) } \\
\text { maximum within grading } \\
\text { section (percent) }\end{array}$ & 9 & f & 50 \\
\hline
\end{tabular}

a Hanks (1976).

b Whenever a 14- or 16-foot section of the butt 16-foot log is better than the best 12 -foot section, the grade of the longer section will become the grade of the tree. This longer section, when used, is the basis for determining the grading factors such as diameter and cull deduction.

c In basswood and ash, d.i.b. at top of grading section must be 12 inches and d.b.h. must be 15 inches.

d Grade 2 trees can be 10 inches d.i.b. at top of grading section if they otherwise meet surface requirements for small grade l's.

e A clear cutting is a portion of a face free of defects, extending the width of the face. A face is one-fourth of the surface of the grading section as divided lengthwise.

f Fifteen percent crook and sweep or 40 percent total cull deduction are permitted in grade 2 trees, if size and surface of grading section qualify as grade 1 . If rot shortens the required clear cuttings to the extent of dropping the butt log to grade 2 , do not drop the tree's grade to 3 unless the cull deduction for rot is greater than 40 percent. 


\section{Forest Service Standard Specifications for Hardwood Construction Logs (tie and timber logs) a, b}

\begin{tabular}{|c|c|}
\hline Position in tree & Butts and uppers \\
\hline Minimum diameter, small end & 8 inches \\
\hline Minimum length without trim & 8 feet \\
\hline Clear cuttings & No requirements \\
\hline Sweep allowance & $\begin{array}{l}\text { One-fourth of the diameter at the small } \\
\text { end for each } 8 \text { feet of length. }\end{array}$ \\
\hline \multicolumn{2}{|l|}{ Sound surface defects: } \\
\hline Single knots & $\begin{array}{l}\text { Any number, if no one knot has an average } \\
\text { diameter above the callus in excess of one-third } \\
\text { of the log diameter at point of occurrence. }\end{array}$ \\
\hline Whorled knots & $\begin{array}{l}\text { Any number, if the sum of knot diameters above } \\
\text { the callus does not exceed one-third of the log } \\
\text { diameter at point of occurrence. }\end{array}$ \\
\hline Holes & $\begin{array}{l}\text { Any number, provided none has a diameter } \\
\text { over one-third of the log diameter at point of } \\
\text { occurrence and none extends more than } 3 \\
\text { inches into included timberc. }\end{array}$ \\
\hline Unsound surface defects: & $\begin{array}{l}\text { Same requirements as for sound defects if } \\
\text { they extend into included timber. } \\
\text { No limit if they do not. }\end{array}$ \\
\hline
\end{tabular}

a Rast et al. (1973).

b These specifications are minimum for the class. If, from a group of logs, factory logs are selected first, thus leaving only nonfactory logs from which to select construction logs, then the quality range of the construction logs so selected is limited, and the class may be considered a grade. If selection for construction logs is given first priority, it may be necessary to subdivide the class into grades.

c Included timber is always square, and dimension is judged from small end. 
Eastern White Pine Saw-log Grade Specifications a

\begin{tabular}{|c|c|c|c|c|}
\hline Grading factor & Log grade 1 & Log grade 2 & Log grade 3 & Log grade 4 \\
\hline $\begin{array}{l}\text { Minimum scaling } \\
\text { diameter (inches) }\end{array}$ & $14^{b}$ & 6 & 6 & 6 \\
\hline $\begin{array}{l}\text { 2. Minimum log } \\
\text { length (feet) }\end{array}$ & $10^{\mathrm{C}}$ & 8 & 8 & 8 \\
\hline $\begin{array}{l}\text { 3. Maximum weevil } \\
\text { injury (number) }\end{array}$ & None & None & 2 injuries $\mathrm{d}$ & No limit \\
\hline $\begin{array}{l}\text { 4. } \text { Minimum face } \\
\text { requirements }\end{array}$ & $\begin{array}{l}\text { Two full } \\
\text { length or } \\
\text { four } 50 \% \mathrm{e} \\
\text { length good } \\
\text { faces (in } \\
\text { addition, log } \\
\text { knots on } \\
\text { balance of } \\
\text { faces shall } \\
\text { not exceed } \\
\text { size limit of } \\
\text { grade } \\
2 \text { logs). }\end{array}$ & $\begin{array}{l}\text { NO GOOD FAC } \\
\text { Maximum dian } \\
\text { on three } \\
\text { SOUND RI } \\
\text { not to exceed } \\
1 / 6 \text { scaling } \\
\text { diameter and } 3 " \\
\text { maximum } \\
\text { OVERGROWN } \\
\text { KNO } \\
\text { not to exceed } \\
1 / 12 \text { scaling } \\
\text { diameter and } \\
11 / 2 " \text { max. }\end{array}$ & $\begin{array}{l}\text { REGÜRED } \\
\text { r of log knots } \\
\text { faces: } \\
\text { KNOTS } \\
\text { not to exceed } \\
1 / 3 \text { scaling } \\
\text { diameter and } \\
5 " \text { maximum } \\
\text { LAD/ BLACK } \\
\text { not to exceed } \\
1 / 6 \text { scaling } \\
\text { diameter and } \\
21 / 2 " \text { max. }\end{array}$ & $\begin{array}{l}\text { Includes all } \\
\text { logs not } \\
\text { qualifying for } \\
\text { No. } 3 \text { or better } \\
\text { and have at } \\
\text { least } 1 / 3 \text { of } \\
\text { their gross } \\
\text { volume in } \\
\text { sound wood } \\
\text { suitable for } \\
\text { manufacture } \\
\text { into standard } \\
\text { lumber }\end{array}$ \\
\hline $\begin{array}{l}\text { 5. Maximum sweep } \\
\text { or crook (percent) }\end{array}$ & 20 & 30 & 40 & $662 / 3$ \\
\hline $\begin{array}{l}\text { 6. Maximum total } \\
\text { scaling } \\
\text { deduction (percent) }\end{array}$ & 50 & 50 & 50 & $662 / 3$ \\
\hline
\end{tabular}

After the tentative log grade is established from face examination, the log will be reduced in grade whenever the following defects are evident:

7. Conks, punk knots, and pine borer damage on bark surface: $f$

Degrade one grade if present on one face.

Degrade two grades if present on two faces.

Degrade three grades if present on three or more faces.

8. Log end defects: red rot, ring shake, heavy stain, and pine borer damage outside the heart center of log. $f$ Consider $\log$ as having a total of 8 quarters (4 on each end) and degrade as indicated.

Degrade one grade if present in 2 quarters of log ends.

Degrade two grades if present in 3 or 4 quarters of log ends.

Degrade three grades if present in 5 or more quarters of log ends.
a. Ostrander and Brisbin (1971)
b. 12- and 13-inch logs with four full-length good faces are acceptable.
c. 8-foot logs with four full-length good faces are acceptable.
d. 8-foot Number 3 logs limited to one weevil injury.
e. Minimum 50\% length good face must be at least 6 feet.
f. Factors 7 and 8 are not cumulative (total degrade based on more serious of the two). No log is to be degraded below grade 4 if net scale is at least one-third of gross scale. 
Grade 1: Trees with three or four clear faces on the 16-foot grading section. $\mathrm{b}$

Grade 2: Trees with one or two clear faces on the 16-foot grading section.

Grade 3: Trees with no clear faces on the 16-foot grading section.

After the tentative grade is established from above, the tree will be reduced one grade for each of the following, except that no tree can be reduced below grade 3, provided the total scaling deductions for sweep and/or rot do not exceed two-thirds of the gross scale of the tree.

Sweep. Degrade any tentative grade 1 or 2 tree one grade if sweep in the lower 12 feet of grading sections amounts to 3 or more inches and equals or exceeds onefourth of the diameter at breast height.

Heart rot. Degrade any tentative grade 1 or 2 tree one grade if conk, punk knots, massed hyphae, or other evidence of advanced heart rot is found anywhere on the main tree stem.

a Campbell (1964).

$\mathrm{b}$ A face is one-fourth of the circumference in width extending full length of the grading section. Clear faces are those free of: knots measuring more than one-half-inch in diameter, overgrown knots of any size, and holes more than one-fourth-inch in diameter. Faces may be rotated to obtain the maximum number of clear ones on the grading section.

\section{Log Grades for All Other Softwood Logs}

Grade 1

1. Trees must be 16 inches in diameter or larger, grading section 12 feet in length or longer, and with deduction for defect not over 30 percent of gross scale.

2. Trees must be at least 75 percent clear on each of three faces.

3. All knots outside clear cutting must be sound and not more than $2-1 / 2$ inches in size.

Grade 2

1. Trees must be 12 inches in diameter or larger, grading section 12 feet in length or longer, and with a net scale after deduction for defect of at least 50 percent of the gross scale deducted for defect.

2. Trees must be at least 50 percent clear on each of three faces or 75 percent clear on two faces.

Grade 3

1. Trees must be 6 inches in diameter or larger, grading section 12 feet in length or longer, and with a net scale after deduction for defect of at least 50 percent of the gross contents of the log.

Note: Diameters are diameter inside bark (d.i.b.) at small end of grading section. Percent clear refers to percent clear in one continuous section. 


\section{METRIC EQUIVALENTS OF UNITS USED IN THIS REPORT}

1 acre $=4,046.86$ square meters or 0.405 hectare.

1,000 acres $=405$ hectares.

1 cubic foot $=0.0283$ cubic meter .

1 foot $=30.48$ centimeters or 0.3048 meter.

1 inch $=25.4$ millimeters, 2.54 centimeters, or 0.0254 meter.

1 pound $=0.454$ kilograms.

1 ton $=0.907$ metric tons.

TREE SPECIES IN THE HURON-MANISTEE NATIONAL FORESTS

(Little 1981)

\section{Softwoods}

Eastern white pine Pinus strobus

Red pine Pinus resinosa

Jack pine Pinus banksiana

White spruce Picea glauca

Black spruce Picea mariana

Balsam fir Abies balsamea

Eastern hemlock Tsuga canadensis

Tamarack Larix laricina

Northern white-cedar Thuja occidentalis

\section{Hardwoods}

Select white oaks ${ }^{1}$

White oak Quercus alba

Bur oak Quercus macrocarpa

Chinkapin oak Quercus muehlenbergii

Swamp white oak Quercus bicolor Other white oaks ${ }^{1}$

Chestnut oak Quercus prinus

Select red oak ${ }^{1}$

Northern red oak Quercus rubra Other red oaks ${ }^{1}$

Scarlet oak Quercus coccinea Northern pin oak

Pin oak Quercus ellipsoidalis

Black oak Quercus palustris . Quercus velutina

Hard maples 1

Black maple Acer nigrum Sugar maple Acer saccharum

Soft maples 2

Red maple Acer rubrum Silver maple Acer saccharinum

1 This species or species group is considered a hard hardwood, with an average specific gravity greater than or equal to 0.50 .

2 This species or species group is considered a soft hardwood, with an average specific gravity of less than 0.50 .
American beech ${ }^{1}$ Fagus grandifolia

Ashes

White ash 1

Black ash 2

Fraxinus americana

Green ash 1 . Fraxinus nigra

Balsam poplar ${ }^{2}$ Aspens 2

Bigtooth aspen

Quaking aspen Fraxinus pennsylvanica . Populus balsamifera Eastern cottonwood ${ }^{2}$ American basswood 2 Populus grandidentata . Populus tremuloides Black cherry ${ }^{2}$ Populus deltoides

Butternut 2

Sycamore ${ }^{2}$ Elms

American elm ${ }^{2}$

Siberian elm ${ }^{2}$

Slippery elm ${ }^{2}$ Tilia americana

Rock elm ${ }^{1}$ Prunus serotina Juglans cinerea Platanus occidentalis Birches $^{2}$

Yellow birch

River birch Ulmus americana Ulmus pumila . Ulmus rubra Ulmus thomasii

Paper birch

Black willow 2

Sassafras ${ }^{2}$

Noncommercial species

Striped maple Mountain maple

Acer pensylvanicum American hornbeam ..... Carpinus caroliniana Hawthorn .......................... Crataegus spp. Apple Malus spp. Eastern hophornbeam ....... Ostrya virginiana Pincherry Prunus pensylvanica Wild plum Prunus spp. Chokecherry Prunus virginiana Peachleaf willow Salix amygdaloides Diamond willow Salix bebbiana

\section{DEFINITION OF TERMS}

\section{Average annual mortality of growing}

stock.-The average cubic foot volume of sound wood in growing-stock trees that died in 1 year. Average annual mortality is the average for the years between inventories (1980 to 1992 in this report).

\section{Average annual mortality of sawtimber.-} The average board foot volume of sound wood in sawtimber trees that died in 1 year. Average annual mortality is the average for the years between inventories (1980 to 1992 in this report). 
Average annual removals from growing

stock.-The average net growing-stock volume in growing-stock trees removed annually for roundwood forest products, in addition to the volume of logging residues, and the volume of other removals. Average annual removals of growing stock are the average for the years between inventories ( 1980 to 1992 in this report) and are based on information obtained from remeasurement plots (see Survey Procedures in Appendix).

\section{Average annual removals from sawtimber.-}

The average net board foot sawtimber volume of live sawtimber trees removed annually for roundwood forest products, in addition to the volume of logging residues, and the volume of other removals. Average annual removals of sawtimber are the average for the years between inventories (1980 to 1992 in this report) and are based on information obtained from remeasurement plots (see Survey Procedures in Appendix).

\section{Average net annual growth of growing} stock. - The annual change in cubic foot volume of sound wood in live sawtimber and poletimber trees, and the total volume of trees entering these classes through ingrowth, less volume losses resulting from natural causes. Average net annual growing stock is the average for the years between inventories (1980 to 1992 in this report).

\section{Average net annual growth of sawtimber.-}

The annual change in the board foot volume of live sawtimber trees, and the total volume of trees reaching sawtimber size, less volume losses resulting from natural causes. Average net annual growth of sawtimber is the average for the years between inventories (1980 to 1992 in this report).

Basal area.-Tree area in square feet of the cross section at breast height of a single tree. When the basal areas of all trees in a stand are summed, the result is usually expressed as square feet of basal area per acre.

Biomass. - The aboveground volume of all live trees (including bark but excluding foliage) reported in green tons (i.e., green weight). Biomass has four components:

Bole.-Biomass of a tree from 1 foot above the ground to a 4-inch top outside bark. Tops and limbs. - Total biomass of tree from a 1-foot stump minus the bole.
1- to 5-inch trees. - Total aboveground biomass of a tree from 1 to 5 inches in diameter at breast height.

Stump.-Biomass of a tree 5 inches d.b.h. and larger from the ground to a height of 1 foot.

Commercial species.-Tree species presently or prospectively suitable for industrial wood products. (Note: Excludes species of typically small size, poor form, or inferior quality such as hophornbeam and redbud.)

Cord.--One standard cord is 128 cubic feet of stacked wood, including bark and air space. Cubic feet can be converted to solid wood standard cords by dividing by 79 .

Corporate. - Lands owned by a private corporation not in the business of operating primary wood-using plants.

County and municipal land.-Land owned by counties and local public agencies or municipalities, or land leased to these governmental units for 50 years or more.

Cropland.-Land under cultivation within the last 24 months; including cropland harvested, crop failures, cultivated summer fallow, idle cropland used only for pasture, orchards, and land in soil improvement crops, but excluding land cultivated in developing improved pasture.

Cull.-Portions of a tree that are unusable for industrial wood products because of rot, missing or dead material, form, or other defect.

\section{Current annual growth of growing stock.-}

The annual change in volume of sound wood in live sawtimber and poletimber trees, and the total volume of trees entering these classes through ingrowth, less volume losses resulting from natural causes, reported for a single year (1992 in this report). Current growth is based on an estimate of the current annual increment of each growing-stock tree in the inventory.

Current annual growth of sawtimber.-The annual change in the volume of live sawtimber trees, and the total volume of trees reaching sawtimber size, less volume losses resulting from natural causes, reported for a single year (1992 in this report). Current 
growth is based on an estimate of the current annual increment of each growingstock tree in the inventory.

\section{Current annual removals from growing} stock.-The current net growing-stock volume in growing-stock trees removed annually for roundwood forest products, in addition to the volume of logging residues, and the volume of other removals. Current annual removals of growing stock are reported for a single year (1992 in this report); they are based on a survey of primary wood processing mills to determine removals for products and on information from remeasurement plots (see Survey Procedures in Appendix) to determine removals due to land use change.

\section{Current annual removals from sawtimber.-}

The current net board foot sawtimber volume of live sawtimber trees removed annually for roundwood forest products, in addition to the volume of logging residues, and the volume of other removals. Current annual removals of sawtimber are reported for a single year (1992 in this report); they are based on a survey of primary wood processing mills to determine removals for products and on information from remeasurement plots (see Survey Procedures in Appendix) to determine removals due to land use change.

\section{Diameter class.-A classification of trees} based on diameter outside bark, measured at breast height 4.5 feet above the ground. (Note d.b.h. is the common abbreviation for diameter at breast height.) Two-inch diameter classes are commonly used in Forest Inventory and Analysis, with the even inch the approximate midpoint for a class. For example, the 6-inch class includes trees $\mathbf{5 . 0}$ through 6.9 inches d.b.h.

\section{Diameter at breast height (d.b.h.).-The} outside bark diameter at 4.5 feet $(1.37 \mathrm{~m})$ above the forest floor on the uphill side of the tree. For determining breast height, the forest floor includes the duff layer that may be present, but does not include unincorporated woody debris that may rise above the ground line.

Farm.-Any place from which $\$ 1,000$ or more of agricultural products were produced and sold during the year.
Farmer-owned land.-(See Individual private land.)

Forest industry land.-Land owned by companies or individuals operating primary wood-using plants.

Forest land.-Land at least 16.7 percent stocked by forest trees of any size, or formerly having had such tree cover, and not currently developed for nonforest use. (Note: Stocking is measured by comparing specified standards with basal area and/or number of trees, age or size, and spacing.) The minimum area for classification of forest land is 1 acre. Roadside, streamside, and shelterbelt strips of timber must have a crown width of at least 120 feet to qualify as forest land. Unimproved roads and trails, streams, or other bodies of water or clearings in forest areas shall be classed as forest if less than 120 feet wide. (See Tree, Land, Timberland, Reserved forest land, Other forest land, Stocking, and Water.)

Forest type.-A classification of forest land based on the species forming a plurality of live tree stocking. These forest types are based on net volume of growing stock and all live biomass on timberland by species group and forest type from the 1993 Michigan inventory. Major forest types in the State are:

Jack pine.-Forests in which jack pine comprises a plurality of the forest stocking. (Common associates include red pine, red oak, aspen,. and eastern white pine.)

Red pine.-Forests in which red pine comprises a plurality of the forest stocking. (Common associates include eastern white pine, jack pine, and aspen.)

Eastern white pine.-Forests in which eastern white pine comprises a plurality of the forest stocking. (Common associates include red pine, aspen, red maple, paper birch, red oak, white spruce, and balsam fir.)

Balsam fir.-Forests in which balsam fir comprises a plurality of the forest stocking. (Common associate include white spruce, aspen, northern white-cedar, paper birch, red maple, black spruce, and eastern white pine.)

White spruce.-Forests in which white spruce comprises a plurality of the forest 
stocking. (Common associates include aspen, paper birch, balsam fir, eastern white pine, red maple, and northern white-cedar.)

Black spruce.-Forests in which black spruce comprises a plurality of the forest stocking. (Common associates include tamarack, balsam fir, eastern white pine, northern white-cedar, aspen, jack pine, and paper birch.)

Northern white-cedar-Forests in which northern white-cedar comprises a plurality of the forest stocking. (Common associates include balsam fir, paper birch, black spruce, red maple, and aspen.)

Tamarack.-Forests in which tamarack comprises a plurality of the forest stocking. (Common associates include northern whitecedar, black spruce, balsam fir, and paper birch.)

Oak-hickory.-Forests in which select red and white oak and other red oak comprise a plurality of the forest stocking. (Common associates include red maple, aspen, and black cherry.)

Elm-ash-soft maple.-Forests in which elmash-soft maple comprises a plurality of the forest stocking. (Common associates include northern white-cedar, aspen, cottonwood, and balsam fir.)

Maple-beech-birch.-Forests in which hard maple, beech, and birch comprise a plurality of the forest stocking. (Common associates include red maple, basswood, hemlock, green and white ash, aspen, black cherry, and select red oak.)

Aspen.-Forests in which aspen comprises a plurality of the forest stocking. (Common associates include red maple, paper birch, balsam fir, and select red oak.)

Paper birch.-Forests in which paper birch comprises a plurality of the forest stocking. (Common associates include aspen, red maple, balsam fir, northern white-cedar, sugar maple, and balsam poplar.)

Balsam poplar.-Forests in which balsam poplar comprises a plurality of the forest stocking. (Common associates include balsam fir, aspen, northern white-cedar, paper birch, black ash, and white spruce.)

Growing-stock tree.-A live tree of commercial species that meets specified standards of size, quality, and merchantability. (Note: Excludes rough, rotten, and dead trees.)

Growing-stock volume.-Net volume in cubic feet of growing-stock trees 5.0 inches d.b.h. and over, from 1 foot above the ground to a minimum 4.0-inch top diameter outside bark of the central stem or to the point where the central stem breaks into limbs.

Hard hardwoods. - Hardwood species with an average specific gravity greater than 0.50 such as oaks, hard maple, hickories, and ash.

Hardwoods.-Dicotyledonous trees, usually broad-leaved and deciduous. (See Soft hardwoods and Hard hardwoods.)

Improved pasture.-Land currently improved for grazing by cultivating, seeding, irrigating, or clearing trees or brush and less than 16.7 percent stocked with trees.

Indian land.-Land held in trust by the United States for tribes or individual Indians.

Individual private land.-Privately owned land not owned by forest industry. This class includes the formerly used Farmer and Miscellaneous private classes.

Industrial wood.-All roundwood products except residential fuelwood.

Land.-(a) Bureau of the Census. Dry land and land temporarily or partly covered by water such as marshes, swamps, and river flood plains (omitting tidal flats below mean high tide); streams, sloughs, estuaries, and canals less than one-eighth of a statute mile wide; and lakes, reservoirs, and ponds less than 40 acres in area.

(b) Forest Inventory and Analysis. The same as the Bureau of the Census, except minimum width of streams, etc., is 120 feet and minimum size of lakes, etc., is 1 acre.

Live trees.-Growing-stock, rough, and rotten trees 1.0 inch d.b.h. and larger.

Log grade.-A log classification based on external characteristics as indicators of quality or value. Log grade was assigned to a sample of softwood sawtimber trees throughout the State during the 1993 inventory. Also see Tree grade. (See Appendix for specific grading factors used.)

Logging residue.-The unused portions of cut trees, plus unused trees killed by logging. 
Marsh.-Nonforest land that characteristically supports low, generally herbaceous or shrubby vegetation, and that is intermittently covered with water.

Merchantable.-Refers to a pulpwood or sawlog section that meets pulpwood or saw-log specifications, respectively.

Miscellaneous Federal land.-Federal land other than National Forest and land administered by the Bureau of Land Management or Bureau of Indian Affairs.

Miscellaneous private land.-(See Individual private land.)

National Forest land.-Federal land that has been legally designated as National Forest or purchase units, and other land administered by the USDA Forest Service.

Net volume.-Gross volume less deductions for rot, sweep, or other defect affecting use for timber products.

Noncommercial species.-Tree species of typically small size, poor form, or inferior quality that normally do not develop into trees suitable for industrial wood products.

Nonforest land.-Land that has never supported forests, and land formerly forested where use for timber management is precluded by development for other uses. (Note: Includes areas used for crops, improved pasture, residential areas, city parks, improved roads of any width and adjoining clearings, powerline clearings of any width, and 1 - to 40-acre areas of water classified by the Bureau of the Census as land.) If intermingled in forest areas, unimproved roads and nonforest strips must be more than 120 feet wide and more than 1 acre in area to qualify as nonforest land.

Nonforest land without trees.-Nonforest land with no live trees present.

Nonforest land with trees.-Nonforest land with one or more trees per acre at least 5 inches d.b.h.

Nonstocked land.-Timberland less than 16.7 percent stocked with all live trees.

Other forest land.-Forest land not capable of producing 20 cubic feet per acre per year of industrial wood crops under natural conditions and not associated with urban or rural development. Many of these sites contain tree species that are not currently utilized for industrial wood production or trees of poor form, small size, or inferior quality that are unfit for most industrial products. Unproductivity may be the result of adverse site conditions such as sterile soil, dry climate, poor drainage, high elevation, and rockiness. This land is not withdrawn from timber utilization.

Other removals.-Growing-stock trees removed but not utilized for products, or trees left standing but "removed" from the timberland classification by land use change. Examples are removals from cultural operations such as timber stand improvement work and land clearing, and the standing volume on land classified originally as timberland but later designated as reserved from timber harvesting (such as a newly established State park).

Ownership size class. - The amount of timberland owned by one owner, regardless of the number of parcels.

Pasture.-Land presently used for grazing or under cultivation to develop grazing.

Physiographic class.-A measure of soil and water conditions that affect tree growth on a site. The physiographic classes are:

Xeric sites.-Very dry soils where excessive drainage seriously limits both growth and species occurrence. Example: sandy jack pine plains.

Xeromesic sites.-Moderately dry soils where excessive drainage limits growth and species occurrence to some extent. Example: dry oak ridge.

Mesic sites.-Deep, well-drained soils. Growth and species occurrence are limited only by climate. Example: well-drained terraces of loamy soil.

Hydromesic sites.-Moderately wet soils where insufficient drainage or infrequent flooding limits growth and species occurrence to some extent. Example: moderately drained bottomland hardwood sites.

Hydric sites.-Very wet sites where excess water seriously limits both growth and species occurrence. Example: frequently flooded river bottoms and black spruce swamps. 
Plant byproducts.-Plant residues used for products such as mulch, pulp chips, and fuelwood.

Plantation.-An artificially reforested area sufficiently productive to qualify as timberland. The planted species is not necessarily predominant. Christmas tree plantations, which are considered reserved forest land, are not included.

Plant residues.-Wood and bark materials generated at manufacturing plants during production of other products.

Poletimber stand.-(See Stand-size class.)

Poletimber tree.-A live tree of commercial species at least 5.0 inches d.b.h., but smaller than sawtimber size.

Potential productivity class.-A classification of forest land in terms of inherent capacity to grow crops of industrial wood. The class identifies the potential growth in merchantable cubic feet/acre/year at culmination of mean annual increment of fully stocked natural stands.

Reserved forest land.-Forest land withdrawn from timber utilization through statute, administrative regulation, designation, or exclusive use for Christmas tree production, as indicated by annual shearing.

Rotten tree.-Live trees of commercial species that do not contain at least one 12-foot saw $\log$ or two saw logs 8 feet or longer, now or prospectively, and/or do not meet regional specifications for freedom from defect primarily because of rot; that is, when more than 50 percent of the cull volume in a tree is rotten.

Rough tree.-(a) Live trees of commercial species that do not contain at least one merchantable 12-foot saw log or two saw logs 8 feet or longer, now or prospectively, and/or do not meet regional specifications for freedom from defect primarily because of roughness or poor form, and (b) all live trees of noncommercial species.

Roundwood products.-Logs, bolts, or other round sections (including chips from roundwood) cut from trees for industrial or consumer uses. (Note: Includes saw logs, veneer logs, and bolts; cooperage logs and bolts; pulpwood; fuelwood; pilings; poles; posts; hewn ties; mine timbers; and various other round, split, or hewn products.)

Salvable dead tree.-A standing or down dead tree considered merchantable by regional standards.

Sapling.-A live tree 1.0 to 5.0 inches d.b.h.

Sapling-seedling stand.--(See Stand-size class.)

Saw log.-A log meeting minimum standards of diameter, length, and defect, including logs at least 8 feet long, sound and straight and with a minimum diameter outside bark (d.o.b.) for softwoods of 7.0 inches $(9.0$ inches for hardwoods) or other combinations of size and defect specified by regional standards.

Saw-log portion.-That part of the bole of sawtimber trees between the stump and the saw-log top.

Saw-log top.-The point on the bole of sawtimber trees above which a saw log cannot be produced. The minimum saw-log top is 7.0 inches d.o.b. for softwoods and 9.0 inches d.o.b. for hardwoods.

Sawtimber stand.-(See Stand-size class.)

Sawtimber tree.-A live tree of commercial species containing at least a 12 -foot saw log or two noncontiguous saw logs 8 feet or longer, and meeting regional specifications for freedom from defect. Softwoods must be at least 9.0 inches d.b.h. Hardwoods must be at least 11.0 inches d.b.h.

Sawtimber volume.-Net volume of the sawlog portion of live sawtimber in board feet, International 1/4-inch rule (unless specified otherwise), from stump to a minimum 7.0 inches top d.o.b. for softwoods and a minimum 9.0 inches top d.o.b. for hardwoods.

Seedling.-A live tree less than 1.0 inch d.b.h. that is expected to survive. Only softwood seedlings more than 6 inches tall and hardwood seedlings more than 1 foot tall are counted. 
Short-log (rough tree).-A sawtimber-size tree of commercial species that contains at least one merchantable 8- to 11 -foot saw log but not a 12 -foot saw log.

Shrub.-A woody, perennial plant differing from a perennial herb in its persistent and woody stem(s) and less definitely from a tree in its lower stature and/or the general absence of a well-defined main stem. For this report, shrubs were separated somewhat arbitrarily into tall and low shrubs as follows:

Tall shrubs. - Shrubs normally taller than 1.6 to 3.2 feet

Low shrubs.-Shrubs normally shorter than 1.6 to 3.2 feet. (Woody perennial vines, such as grape, were included with low shrubs.)

Shrub and tree seedling biomass. - The total aboveground weight of trees less than 1.0 inch in diameter and all shrubs.

Site index.-An expression of forest site quality based on the height of a free-growing dominant or codominant tree of a representative species in the forest type at age 50.

Soft hardwoods. - Hardwood species with an average specific gravity less than 0.50 , such as cottonwood, red maple, basswood, and willow.

Softwoods.-Coniferous trees, usually evergreen, having needles or scale-like leaves.

Stand.-A group of trees on a minimum of 1 acre of forest land that is stocked by forest trees of any size.

\section{Stand-age class.-A classification based on} age of the main stand. Main stand refers to trees of the dominant forest type and standsize class.

Stand-size class.-A classification of stocked (see Stocking) forest land based on the size class of live trees on the area; that is, sawtimber, poletimber, or seedlings and saplings.

Sawtimber stands.-Stands with half or more of live tree stocking in sawtimber or poletimber trees, and with sawtimber stocking at least equal to poletimber stocking.

Poletimber stands.-Stands with half or more of live tree stocking in poletimber and/ or sawtimber trees, and with poletimber stocking exceeding that of sawtimber.

Sapling-seedling stands. - Stands with more than half of the live tree stocking in saplings and/or seedlings.

State land.--Land owned by the State of Michigan or leased to it for 50 years or more.

Stocking.-The degree of occupancy of land by live trees, measured by basal area and/or the number of trees in a stand by size or age and spacing, compared to the basal area and/or number of trees required to fully utilize the growth potential of the land; that is, the stocking standard. A stocking percent of 100 indicates full utilization of the site and is equivalent to 80 square feet of basal area per acre in trees 5.0 inches d.b.h. and larger. In a stand of trees less than 5 inches d.b.h., a stocking percent of 100 would indicate that the present number of trees is sufficient to produce 80 square feet of basal area per acre when the trees reach 5 inches d.b.h.

Stands are grouped into the following stocking classes:

Overstocked stands.-Stands in which stocking of live trees is 133.0 percent or more.

Fully stocked stands. - Stands in which stocking of live trees is from 100.0 to 132.9 percent.

Medium stocked stands.- Stands in which stocking of live trees is from 60.0 to 99.9 percent.

Poorly stocked stands.-Stands in which stocking of live trees is from 16.7 to 59.9 percent.

Nonstocked areas.-Timberland on which stocking of live trees is less than 16.7 percent.

Timber products output.-All timber products cut from roundwood and byproducts of wood manufacturing plants. Roundwood products include logs, bolts, or other round sections cut from growing-stock trees, cull trees, salvable dead trees, trees on nonforest land, noncommercial species, sapling-size trees, and limbwood. Byproducts from primary manufacturing plants include slabs, edging, trimmings, miscuts, sawdust, shavings, veneer cores and clippings, and screenings of pulpmills that are used as pulpwood chips or other products. 
Timberland.-Forest land that is producing, or is capable of producing, more than 20 cubic feet per acre per year of industrial wood crops under natural conditions, that is not withdrawn from timber utilization, and that is not associated with urban or rural development. Currently inaccessible and inoperable areas are included. (Timberland was formerly called commercial forest land.)

Tree.-A woody plant usually having one or more perennial stems, a more or less definitely formed crown of foliage, and a height of at least 12 feet at maturity.

Tree biomass.-The total aboveground weight (including the bark but excluding the foliage) of all trees from 1 to 5 inches in d.b.h., and the total aboveground weight (including the bark but excluding the foliage) from a 1 -foot stump for trees more than 5 inches in diameter.

Tree grade.-A classification of the lower 16 feet of the bole of standing trees based on external characteristics as indicators of the quality and quantity of lumber that could be produced from the tree. Tree grade was assigned to a sample of hardwood sawtimber trees during the 1993 inventory. Also see Log grade. (See Appendix for specific grading factors used.)

Tree size class.-A classification of trees based on diameter at breast height, including sawtimber trees, poletimber trees, saplings, and seedlings.

Upper stem portion.-That part of the bole of sawtimber trees above the saw-log top to a minimum top diameter of 4.0 inches d.o.b. or to the point where the central stem breaks into limbs.

Urban and other areas.-Areas within the legal boundaries of cities and towns; suburban areas developed for residential, industrial, or recreational purposes; school yards; cemeteries; roads; railroads; airports; beaches; powerlines and other rights-of-way; or other nonforest land not included in any other specified land use class.
Urban forest land.-Land that would otherwise meet the criteria for timberland, but is in an urban-suburban area surrounded by commercial, industrial, or residential development and not likely to be managed for the production of industrial wood products on a continuing basis. Wood removed would be for land clearing, fuelwood, or esthetic purposes. Such forest land may be associated with industrial, commercial, residential subdivision, industrial parks, golf course perimeters, airport buffer strips, and public urban parks that qualify as forest land.

Water.- (a) Bureau of the Census.-Permanent inland water surfaces, such as lakes, reservoirs, and ponds at least 40 acres in area; and streams, sloughs, estuaries, and canals at least one-eighth of a statute mile wide.

(b) Noncensus.-Permanent inland water surfaces, such as lakes, reservoirs, and ponds from 1 to 39.9 acres in area; and streams, sloughs, estuaries, and canals from 120 feet to one-eighth of a statute mile wide.

Wooded pasture.-Improved pasture with more than 16.7 percent stocking in live trees, but less than 25 percent stocking in growing-stock trees. Area is currently improved for grazing or there is other evidence of grazing.

Wooded strip.-An acre or more of natural continuous forest land that would otherwise meet survey standards for timberland except that it is less than 120 feet wide.

\section{LITERATURE CITED}

Belcher, D.W.; Holdaway, M.R.; Brand, G.J. 1982. A description of STEMS the Stand and Tree Evaluation and Modeling System. Gen. Tech. Rep NC-79. St. Paul, MN: U.S. Department of Agriculture, Forest Service, North Central Forest Experiment Station. 18 p.

Campbell, R.A. 1964. Forest Service log grades for southern pine. Res. Pap. SE-11. Asheville, NC: U.S. Department of Agriculture, Forest Service, Southeastern Forest Experiment Station. 17 p. 
Hahn, J.T. 1984. Tree volume and biomass equations for the Lake States. Res. Pap. NC-250. St. Paul, MN: U.S. Department of Agriculture, Forest Service, North Central Forest Experiment Station. 10 p.

Hanks, L.F. 1976. Hardwood tree grades for factory lumber. Res. Pap. NE-333. Broomall, PA: U.S. Department of Agriculture, Forest Service, Northeastern Forest Experiment Station. $81 \mathrm{p}$.

Hansen, M.H. 1990. A comprehensive sampling system for forest inventory based on an individual tree growth model. St. Paul, MN: University of Minnesota, College of Natural Resources. 256 p. Ph.D. dissertation.

\section{Little, Elbert L. 1981. Check list of native} and naturalized trees of the United States. Agric. Handb. 541. Washington, DC: U.S. Department of Agriculture, Forest Service. 385 p.

Loetsch, F.; Haller, K.E. 1964. Forest inventory, volume I, statistics of forest inventory and information from aerial photographs. Vienna: BLV Verlagsgesellschaft Munch Basle. 436 p.

Ostrander, M.D.; Brisbin, R.L. 1971 . Sawlog grades for eastern white pine. Res. Pap. NE-205. Upper Darby, PA: U.S. Department of Agriculture, Forest Service, Northeastern Forest Experiment Station. 24 p.

Rast, Everette D.; Sonderman, David L.; Gammon, Glenn L. 1973. A guide to hardwood log grading. Gen. Tech. Rep. NE-1. Upper Darby, PA: U.S. Department of Agriculture, Forest Service, Northeastern Forest Experiment Station. 31 p.

\section{Smith, W.B. 1983. Adjusting the STEMS} regional growth models to improve local predictions. Res. Note NC-297. St. Paul, MN: U.S. Department of Agriculture, Forest Service, North Central Forest Experiment Station. 5 p.

Van Deusen, P.C.; Dell, T.R.; Thomas, C.E. 1986. Volume growth estimation from permanent horizontal points. Forest Science. 32: 415-422.
Wiant, Harry V., Jr.; Castenaeda, Froylan. 1977. Mesavage and Girard's volume tables formulated. BLM4. Denver, CO: USDI, Bureau of Land Management, Denver Service Center: 1- 4.

\section{Table Titles}

Table 1.-Area by Forest and major land-use class, Huron-Manistee National Forests, 1993

Table 2.-Area of timberland by forest type and stand-size class, HuronManistee National Forests, 1993

Table 3.-Area of timberland by forest type and stand-age class, HuronManistee National Forests, 1993

Table 4.-Area of timberland by forest type and potential productivity class, Huron-Manistee National Forests, 1993

Table 5.-Area of timberland by forest type and stocking class of growing-stock trees, Huron-Manistee National Forests, 1993

Table 6.-Number of all live trees on timberland by species group and diameter class, Huron-Manistee National Forests, 1993

Table 7.-Net volume of all live, growing-stock, and sawtimber trees on timberland by Forests and major species group, Huron-Manistee National Forests, 1993

Table 8.-Net volume of all live trees on timberland by species group and forest type, Huron-Manistee National Forests, 1993

Table 9.-Net volume of growing stock on timberland by species group and diameter class, Huron-Manistee National Forests, 1993

Table 10.-Net volume of sawtimber on timberland by species group and diameter class, Huron-Manistee National Forests, 1993

Table 11.-Net volume of all live trees and salvable dead trees on timberland by class of timber and major species group, Huron-Manistee National Forests, 1993 
Table 12.-Average net annual growth of growing stock and sawtimber on timberland by Forest and major species group, Huron-Manistee National Forests, 1980-1993

Table 13.-Average annual removals of growing stock and sawtimber on timberland by Forest and major species group, Huron-Manistee National Forests, 1980-1993
Table 14.-Average net annual growth, average annual mortality, and average annual removals of growing stock and sawtimber on timberland by species group, Huron-Manistee National Forests, 1980-1992

Table 15.-Volume of sawtimber on timberland by species group and butt log grade or tree grade, HuronManistee National Forests, 1993 
Table 1.--Area by Forest and major land-use class, Huron-Manistee National Forests, 1993

(In thousand acres)

\begin{tabular}{|c|c|c|c|c|c|c|}
\hline \multirow[b]{2}{*}{$\begin{array}{l}\text { National } \\
\text { Forest } \\
\end{array}$} & \multirow[b]{2}{*}{$\begin{array}{l}\text { Total } \\
\text { land } \\
\text { area } \\
\end{array}$} & \multicolumn{4}{|c|}{ Forest land } & \multirow[b]{2}{*}{$\begin{array}{r}\text { Non- } \\
\text { forest } \\
\text { land }\end{array}$} \\
\hline & & $\begin{array}{r}\text { All } \\
\text { forest } \\
\text { land } \\
\end{array}$ & $\begin{array}{r}\text { Timber- } \\
\text { land }\end{array}$ & $\begin{array}{r}\text { Reserved } \\
\text { timber- } \\
\text { land }\end{array}$ & $\begin{array}{c}\text { Other } \\
\text { forest } \\
\text { land }\end{array}$ & \\
\hline Huron & 436.4 & 425.0 & 406.8 & 16.4 & 1.8 & 11.4 \\
\hline Manistee & 528.5 & 526.1 & 508.3 & 17.8 & - & 2.4 \\
\hline Total & 964.9 & 951.1 & 915.1 & 34.2 & 1.8 & 13.8 \\
\hline
\end{tabular}


Table 2.--Area of timberland by forest type and stand-size class, Huron-Manistee National Forests, 1993

(In thousand acres)

\begin{tabular}{lrrrr}
\hline & All & & \multicolumn{3}{c}{ Stand-size class } \\
\cline { 3 - 5 } Forest type & stands & Sawtimber & Poletimber & $\begin{array}{r}\text { Sapling \& } \\
\text { seedling }\end{array}$ \\
\hline Jack pine & 123.9 & 12.2 & 53.0 & 58.7 \\
Red pine & 189.1 & 74.0 & 97.9 & 17.2 \\
White pine & 12.4 & 8.1 & 4.3 & - \\
Balsam fir & 6.8 & - & 4.1 & 2.7 \\
Black spruce & 1.9 & - & - & 1.9 \\
Northern white-cedar & 23.2 & 9.8 & 13.4 & - \\
Tamarack & 1.8 & - & - & 1.8 \\
Oak-hickory & 251.3 & 105.9 & 98.5 & 46.9 \\
Elm-ash-soft maple & 47.7 & 31.2 & 14.2 & 2.3 \\
Maple-beech-birch & 133.1 & 56.8 & 55.9 & 20.4 \\
Aspen & 113.4 & 28.5 & 46.6 & 38.3 \\
Paper birch & 3.9 & 3.9 & - & - \\
Balsam poplar & 6.6 & - & 2.4 & 4.2 \\
Total & 915.1 & 330.4 & 390.3 & 194.4 \\
\hline
\end{tabular}


Table 3.--Area of timberland by forest type and stand-age class, Huron-Manistee National Forests, 1993

(In thousand acres)

\begin{tabular}{lrrrrrrrrr}
\hline & All & \multicolumn{7}{c}{ Stand-age class (years) } \\
\cline { 3 - 10 } Forest type & ages & $1-20$ & $21-40$ & $41-60$ & $61-80$ & $81-100$ & $101-120$ & $121-140$ & $141+$ \\
\hline Jack pine & 123.9 & 45.4 & 36.9 & 34.9 & 5.1 & 1.6 & - & - & - \\
Red pine & 189.1 & 18.4 & 88.8 & 70.8 & 5.9 & 5.2 & - & - & - \\
White pine & 12.4 & - & 1.6 & 6.1 & 4.7 & - & - & - & - \\
Balsam fir & 6.8 & - & 2.7 & - & 4.1 & - & - & - & - \\
Black spruce & 1.9 & - & 1.9 & - & - & - & - & - & - \\
Northem white-cedar & 23.2 & - & 1.2 & 4.6 & 3.5 & 10.5 & 1.6 & - & 1.8 \\
Tamarack & 1.8 & - & 1.8 & - & - & - & - & - & - \\
Oak-hickory & 251.3 & 43.1 & 29.3 & 84.1 & 60.8 & 18.7 & 12.9 & 2.4 & - \\
Elm-ash-soft maple & 47.7 & 2.3 & 5.6 & 21.4 & 7.3 & 7.3 & 2.4 & 1.4 & - \\
Maple-beech-birch & 133.1 & 16.1 & 32.7 & 48.4 & 21.2 & 10.7 & 1.3 & - & 2.7 \\
Aspen & 113.4 & 34.8 & 33.4 & 20.8 & 17.0 & 5.8 & 1.6 & - & - \\
Paper birch & 3.9 & - & - & - & 3.9 & - & - & - & - \\
Balsam poplar & 6.6 & 4.2 & - & 2.4 & - & - & - & - & - \\
Total & 915.1 & 164.3 & 235.9 & 293.5 & 133.5 & 59.8 & 19.8 & 3.8 & 4.5 \\
\hline
\end{tabular}


Table 4.--Area of timberland by forest type and potential productivity class,

Huron-Manistee National Forests, 1993

(In thousand acres)

\begin{tabular}{lrrrrrr}
\hline & \multicolumn{6}{c}{ Potential productivity class (cubic feet of growth per acre per year) } \\
\cline { 2 - 7 } Forest type & All & & & & & \\
\hline Jack pine & classes & $165+$ & $120-164$ & $85-119$ & $50-84$ & $20-49$ \\
Red pine & 123.9 & - & - & - & 22.2 & 101.7 \\
White pine & 189.1 & - & 41.9 & 79.3 & 53.2 & 14.7 \\
Balsam fir & 12.4 & - & 2.2 & 2.5 & 2.7 & 5.0 \\
Black spruce & 6.8 & - & 2.7 & 4.1 & - & - \\
Northern white-cedar & 1.9 & - & - & - & - & 1.9 \\
Tamarack & 23.2 & - & - & - & 11.8 & 11.4 \\
Oak-hickory & 1.8 & - & - & - & - & 1.8 \\
Elm-ash-soft maple & 251.3 & - & - & 35.3 & 124.6 & 91.4 \\
Maple-beech-birch & 47.7 & - & - & 11.2 & 20.6 & 15.9 \\
Aspen & 133.1 & - & - & 37.2 & 70.4 & 25.5 \\
Paper birch & 113.4 & 0.5 & 9.3 & 40.1 & 48.8 & 14.7 \\
Balsam poplar & 3.9 & - & - & 1.5 & 2.4 & - \\
Total & 6.6 & - & - & 3.9 & 2.7 & - \\
\hline
\end{tabular}




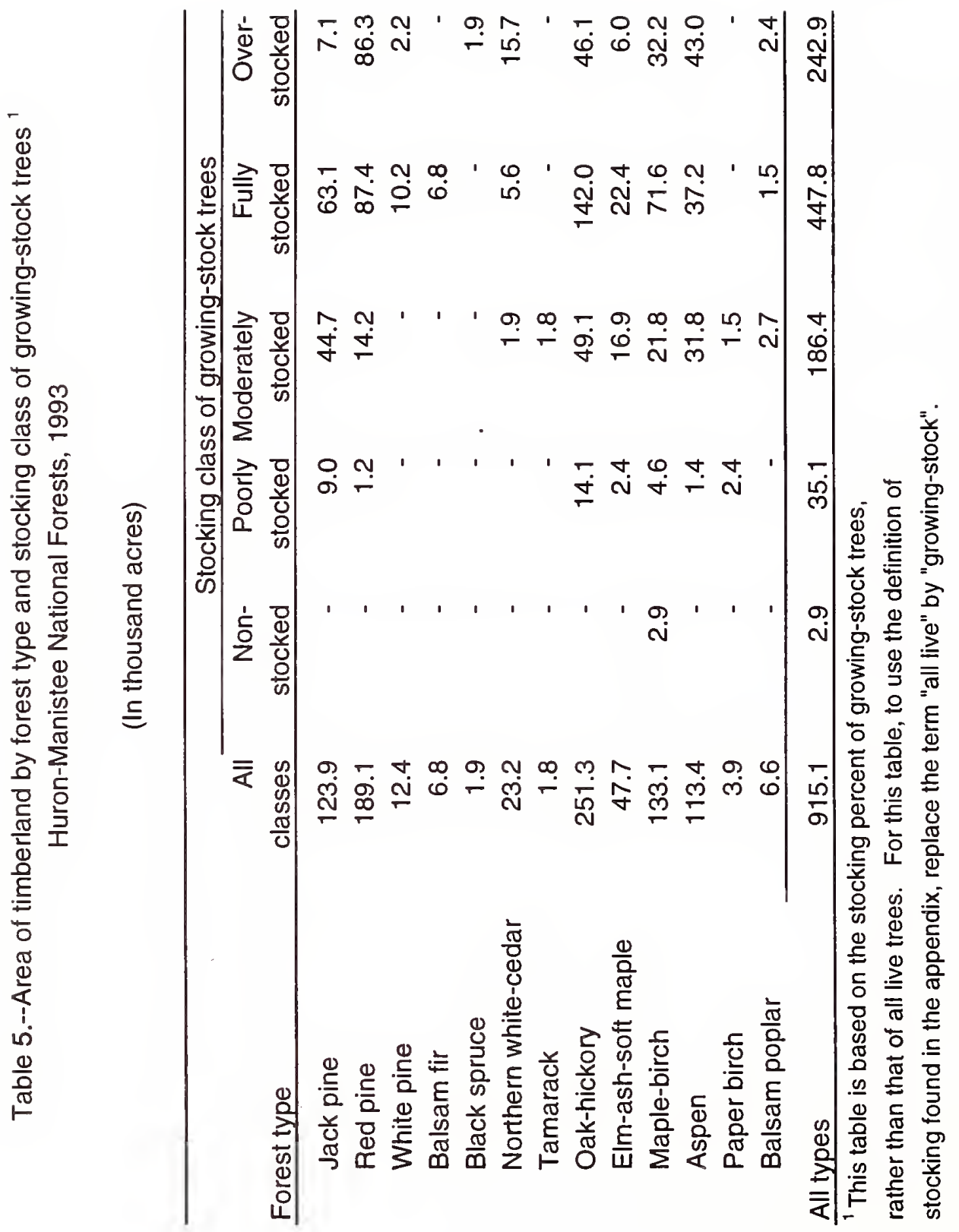




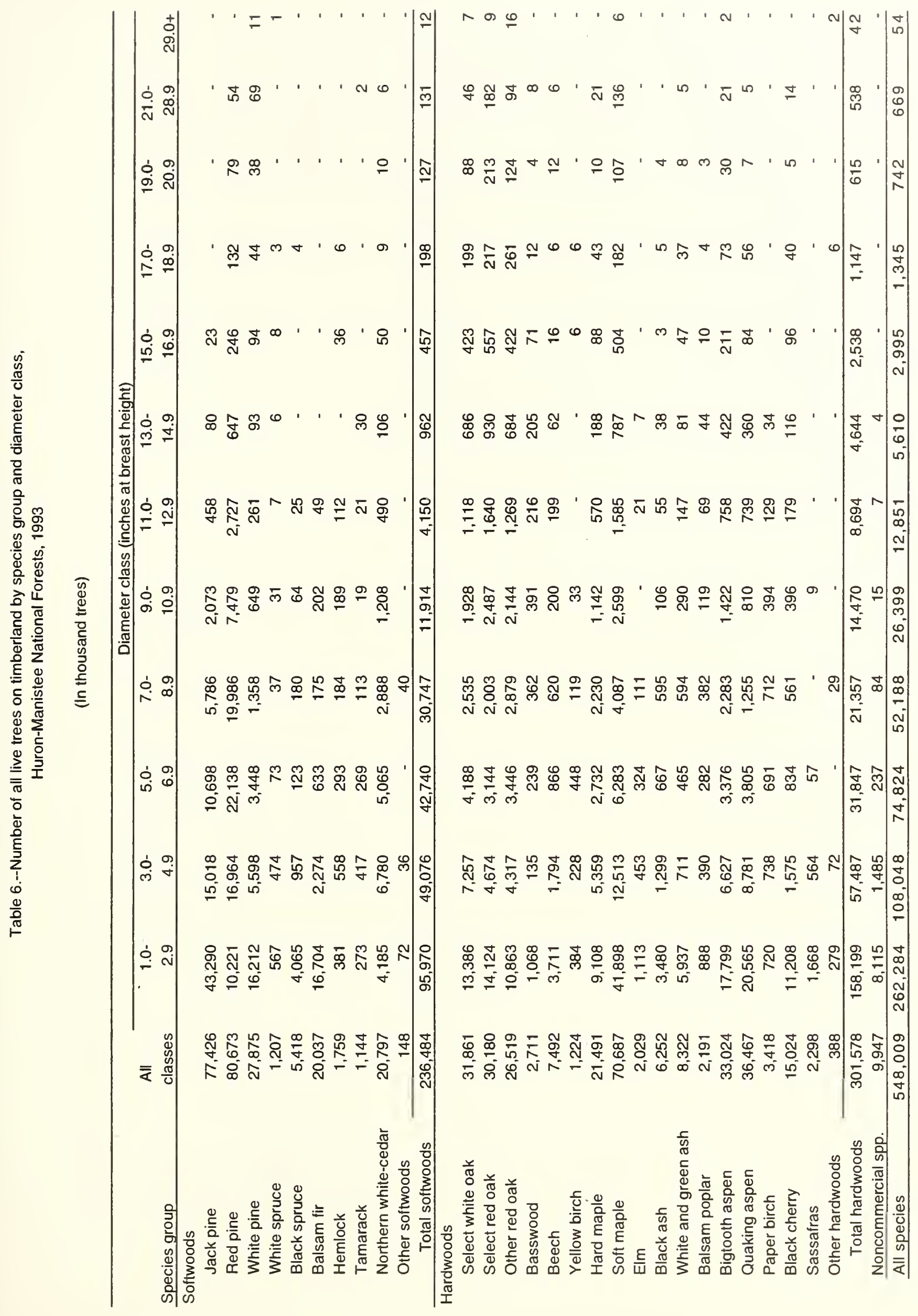




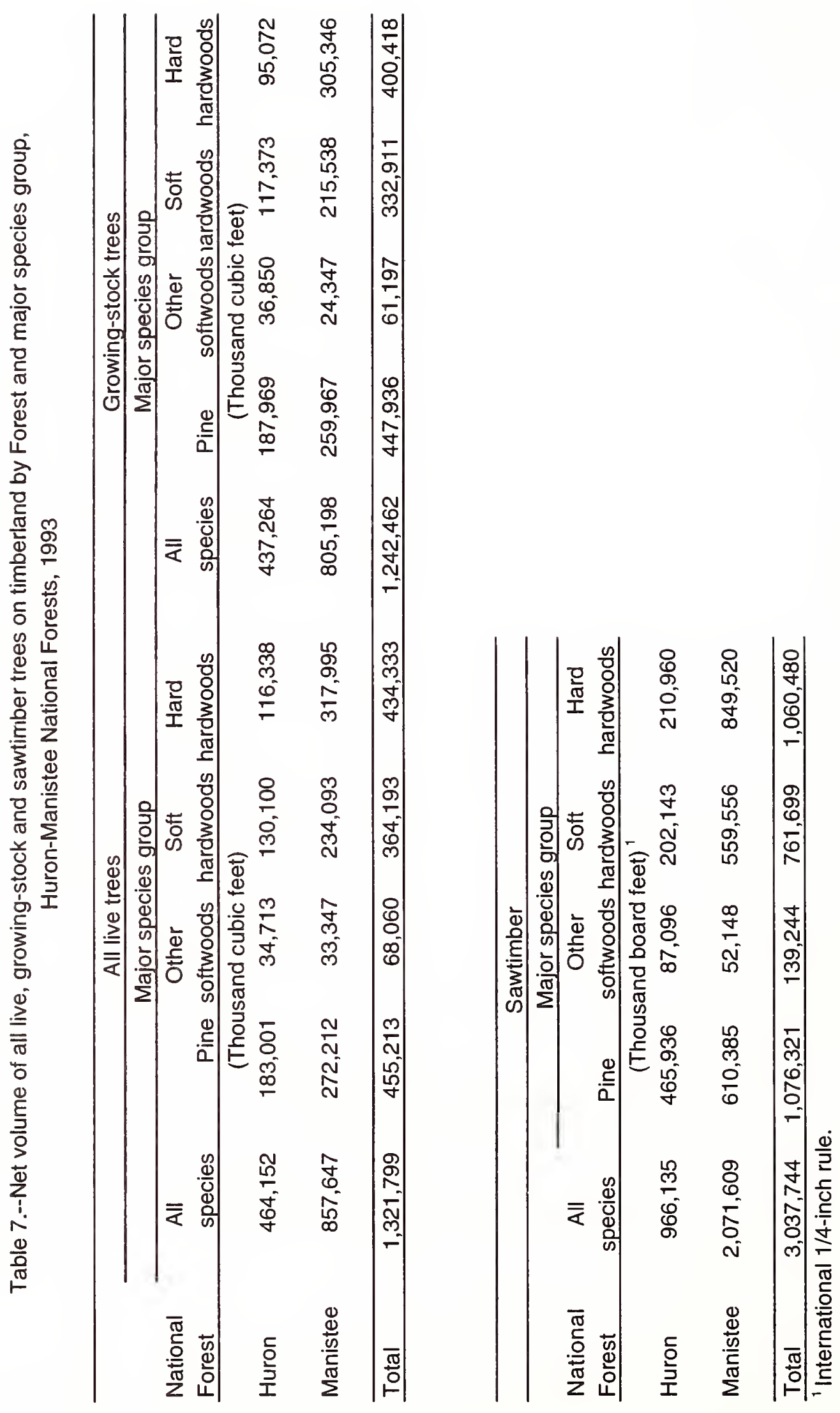




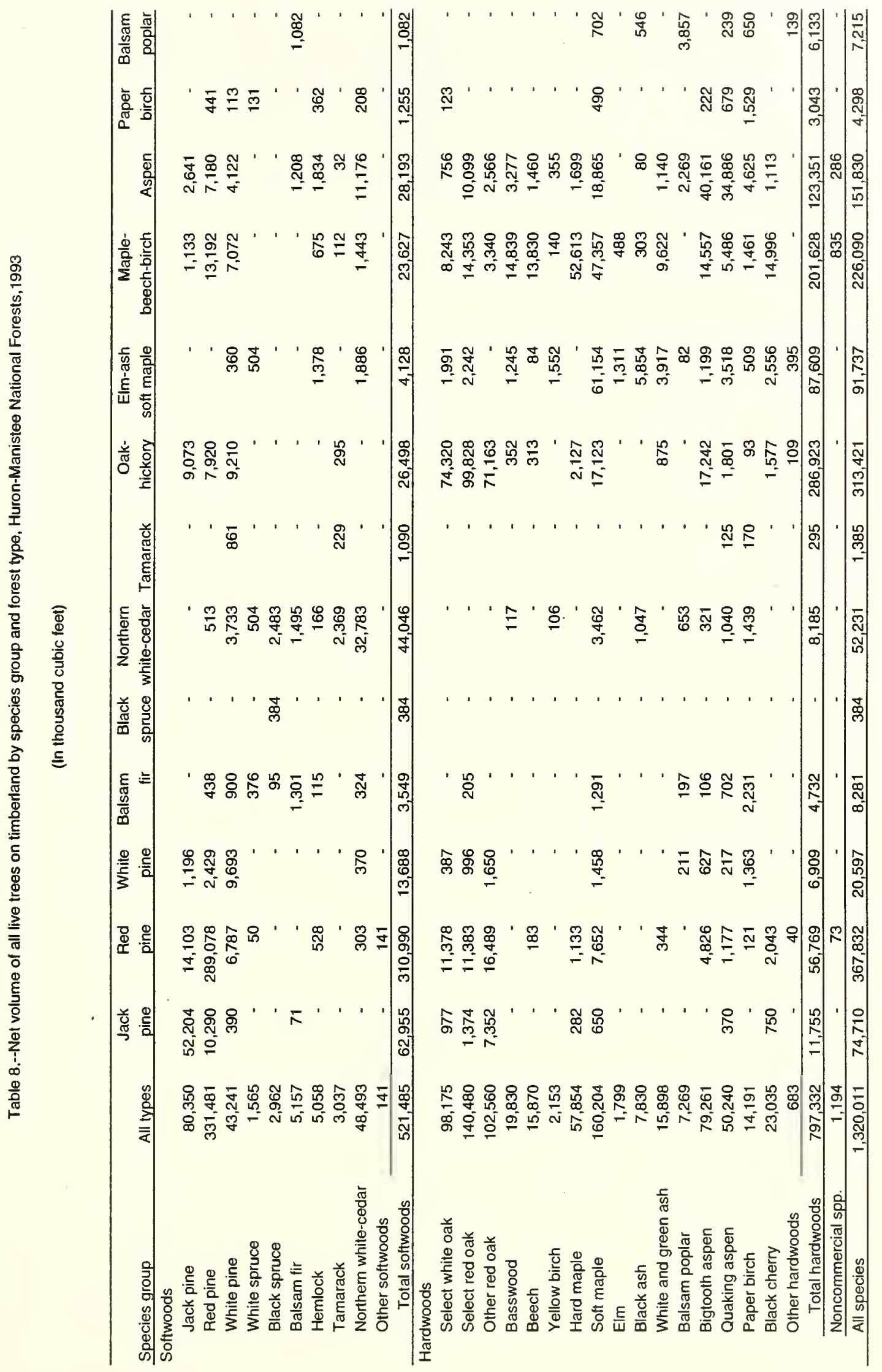




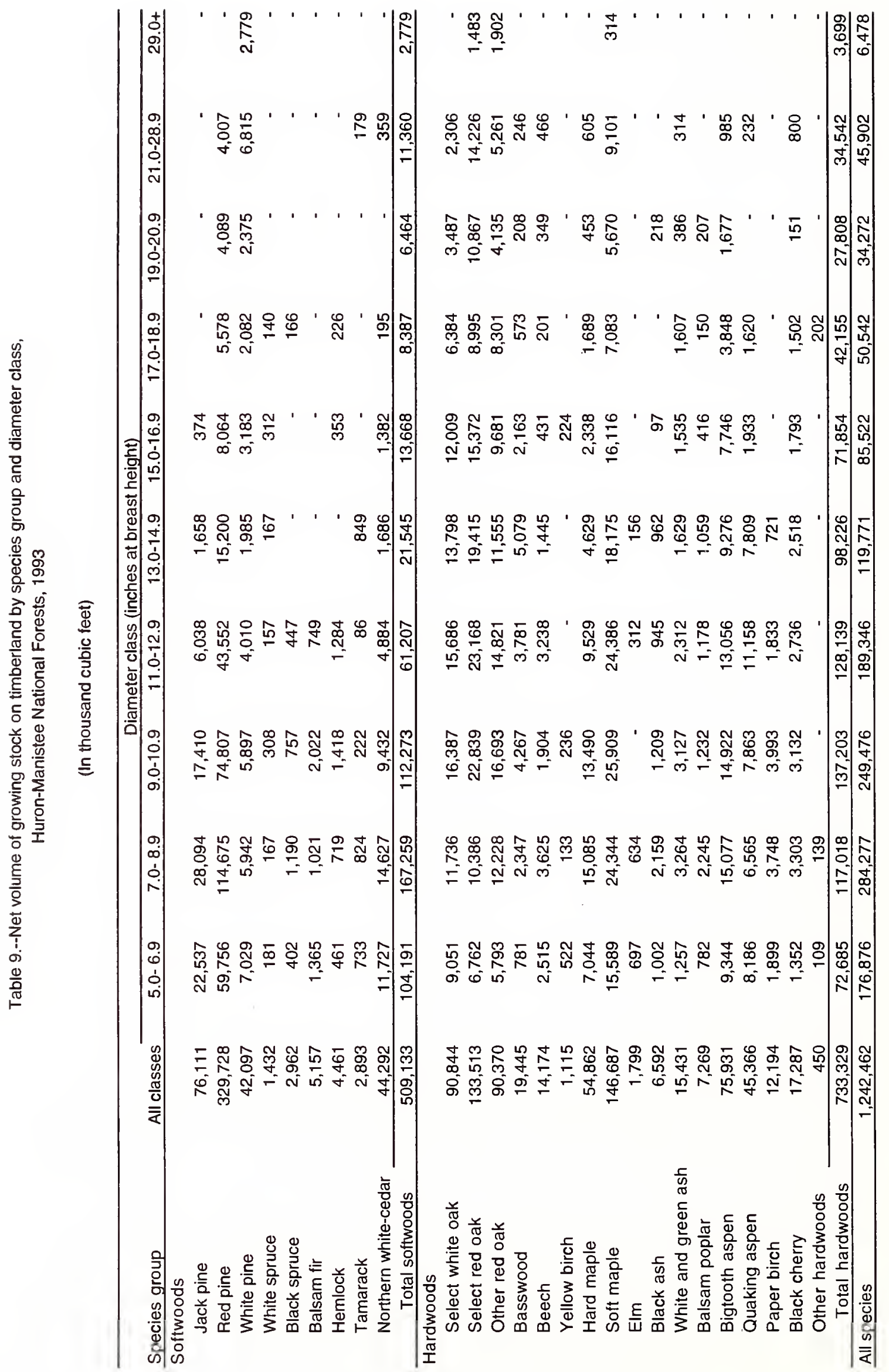




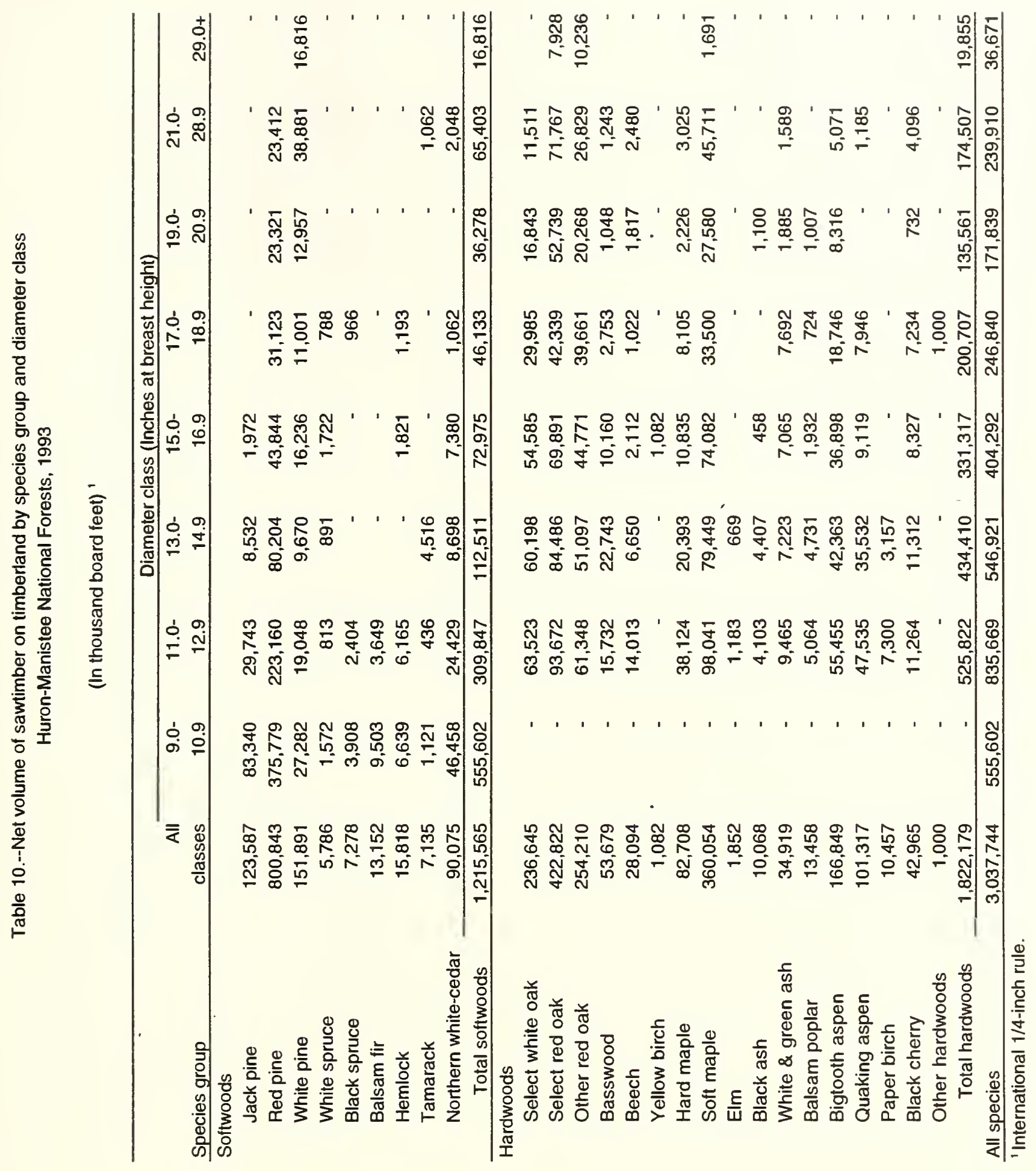




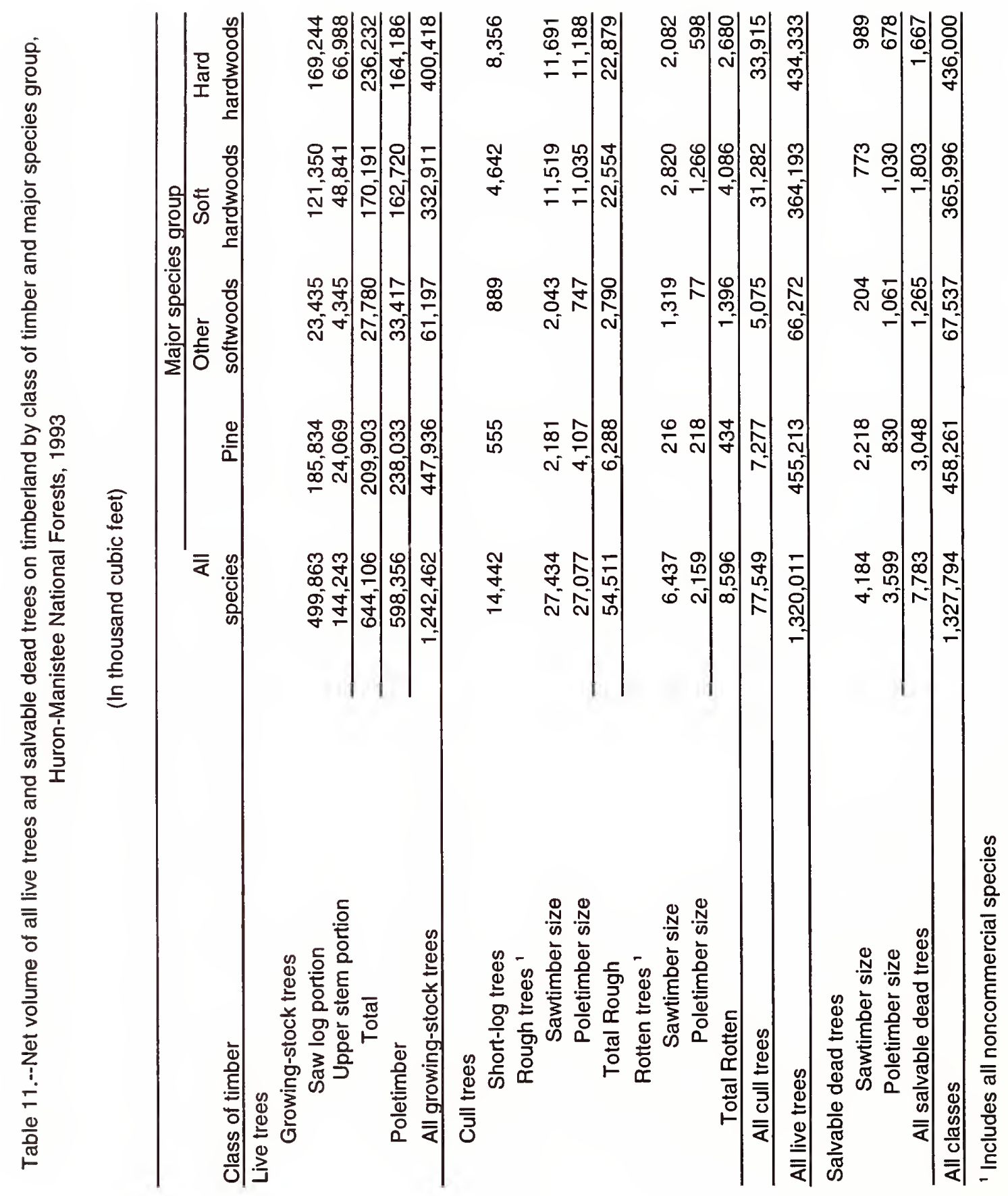




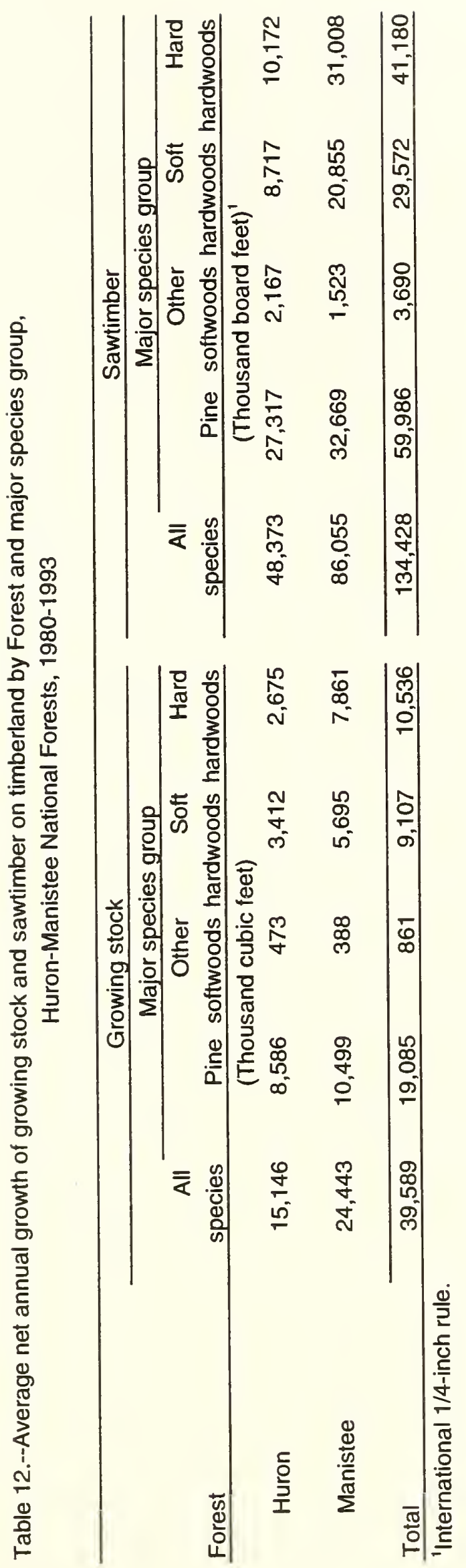




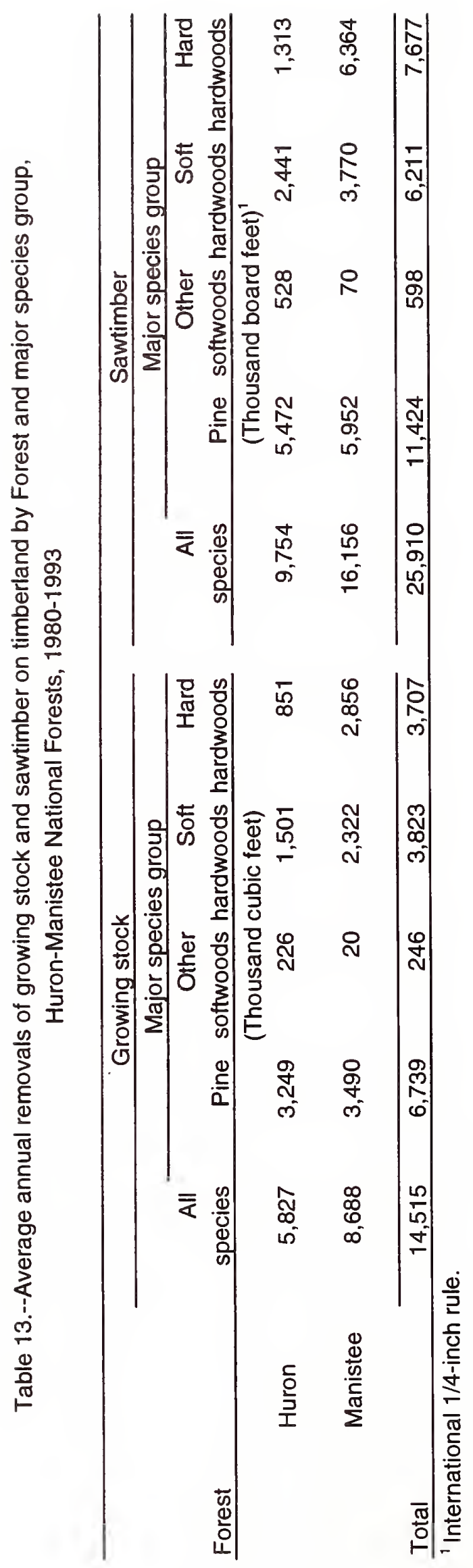


Table 14,---Average net annual growth, average annual mortality, and average annual removals of growing stock and sawtimber on timberland by species group,

Huron-Manistee National Forests, 1980-1992

\begin{tabular}{|c|c|c|c|c|c|c|}
\hline \multirow[b]{2}{*}{ Species group } & \multicolumn{3}{|c|}{ Growing stock } & \multicolumn{3}{|c|}{ Sawtimber } \\
\hline & $\begin{array}{r}\text { Average } \\
\text { net annual } \\
\text { growth } \\
\end{array}$ & $\begin{array}{r}\text { Average } \\
\text { net annual } \\
\text { mortality } \\
\end{array}$ & $\begin{array}{r}\text { Average } \\
\text { annual } \\
\text { removals } \\
\end{array}$ & $\begin{array}{r}\text { Average } \\
\text { net annual } \\
\text { growth } \\
\end{array}$ & $\begin{array}{r}\text { Average } \\
\text { annual } \\
\text { mortality }\end{array}$ & $\begin{array}{r}\text { Average } \\
\text { annual } \\
\text { removals }\end{array}$ \\
\hline & \multicolumn{3}{|c|}{ (Thousand cubic feet) } & \multicolumn{3}{|c|}{ (Thousand board feet)' } \\
\hline \multicolumn{7}{|l|}{ Softwoods } \\
\hline Jack pine & 1,756 & 1,573 & 2,410 & 5,613 & 2,221 & 3,038 \\
\hline Red pine & 15,310 & 157 & 4,071 & 47,453 & 227 & 7,086 \\
\hline White pine & 2,019 & 184 & 258 & 6,920 & 846 & 1,300 \\
\hline White spruce & 38 & 54 & 85 & -28 & 290 & 160 \\
\hline Black spruce & -6 & 72 & - & -210 & 305 & - \\
\hline Balsam fir & -188 & 333 & 111 & 110 & 139 & 290 \\
\hline Hemlock & 91 & 37 & 14 & 561 & 187 & 70 \\
\hline Tamarack & 79 & 16 & - & 123 & 10 & - \\
\hline \multirow{2}{*}{$\begin{array}{c}\text { Northern white-cedar } \\
\text { Total softwoods }\end{array}$} & 847 & 168 & 36 & 3,134 & 171 & 78 \\
\hline & 19,946 & 2,594 & 6,985 & 63,676 & 4,396 & 12,022 \\
\hline \multicolumn{7}{|l|}{ Hardwoods } \\
\hline Select white oak & 2,220 & 69 & 1,077 & 8,436 & 75 & 2,281 \\
\hline Select red oak & 3,992 & 542 & 833 & 18,071 & 799 & 2,467 \\
\hline Other red oak & 1,791 & 362 & 1,197 & 8,736 & 611 & 2,497 \\
\hline Basswood & 217 & 166 & 276 & 1,882 & 395 & 486 \\
\hline Beech & 424 & 24 & 59 & 904 & 34 & - \\
\hline Yellow birch & - & 38 & 27 & 2 & - & - \\
\hline Hard maple & 1,597 & 132 & 217 & 3,492 & 286 & 167 \\
\hline Soft maple & 4,119 & 487 & 1,592 & 14,268 & 958 & 2,382 \\
\hline Elm & 33 & 73 & 28 & -40 & 137 & - \\
\hline Black ash & -9 & 160 & 99 & 271 & 282 & 129 \\
\hline White \& green ash & 506 & 66 & 297 & 1,539 & 178 & 265 \\
\hline Balsam poplar & 368 & 103 & 48 & 740 & 217 & 116 \\
\hline Bigtooth aspen & 2,532 & 659 & 624 & 6,175 & 1,128 & 1,085 \\
\hline Quaking aspen & 1,447 & 840 & 670 & 4,957 & 1,292 & 1,609 \\
\hline Paper birch & 1 & 301 & 311 & 165 & 284 & 87 \\
\hline Black cherry & 474 & 46 & 175 & 1,619 & 68 & 317 \\
\hline Other hardwoods & -69 & 87 & - & -465 & 466 & - \\
\hline Total hardwoods & 19,643 & 4,155 & 7,530 & 70,752 & 7,210 & 13,888 \\
\hline All species & 39,589 & 6,749 & 14,515 & 134,428 & 11,606 & 25,910 \\
\hline
\end{tabular}

${ }^{1}$ International $1 / 4$-inch rule. 
Table 15.--Volume of sawtimber on timberland by species group and butt log grade or tree grade, Huron-Manistee National Forests, 1993

(In thousand board feet) ${ }^{1}$

\begin{tabular}{|c|c|c|c|c|c|}
\hline \multirow[b]{2}{*}{ Species } & \multicolumn{5}{|c|}{ Butt log grade } \\
\hline & grades & 1 & 2 & 3 & 4 \\
\hline \multicolumn{6}{|l|}{ Softwoods } \\
\hline Jack pine & 123,587 & 1,362 & - & 122,225 & - \\
\hline Red pine & 800,843 & 4,234 & 10,344 & 786,265 & - \\
\hline White pine & 151,891 & 7,437 & 35,091 & 97,895 & 11,468 \\
\hline White spruce & 5,786 & - & - & 5,786 & - \\
\hline Black spruce & 7,278 & - & - & 7,278 & - \\
\hline Balsam fir & 13,152 & - & - & 13,152 & - \\
\hline Hemlock & 15,818 & - & 2,056 & 13,762 & - \\
\hline Tamarack & 7,135 & - & - & 7,135 & - \\
\hline \multirow{4}{*}{$\begin{array}{c}\text { Northern white-cedar } \\
\text { Total softwoods }\end{array}$} & 90,075 & - & - & 90,075 & - \\
\hline & $1,215,565$ & 13,033 & 47,491 & $1,143,573$ & 11,468 \\
\hline & \multicolumn{5}{|c|}{ Tree grade } \\
\hline & $\begin{array}{c}\text { All } \\
\text { grades }\end{array}$ & 1 & 2 & 3 & $\begin{array}{c}\text { Tie } \\
\text { and timber }\end{array}$ \\
\hline \multicolumn{6}{|l|}{ Hardwoods } \\
\hline Select white oak & 236,645 & 17,250 & 71,585 & 113,548 & 34,262 \\
\hline Select red oak & 422,822 & 97,878 & 142,001 & 143,800 & 39,143 \\
\hline Other red oak & 254,210 & 18,234 & 43,447 & 124,243 & 68,286 \\
\hline Basswood & 53,679 & 2,080 & 34,857 & 16,741 & - \\
\hline Beech & 28,094 & - & 1,338 & 16,619 & 10,137 \\
\hline Yellow birch & 1,082 & - & 52 & 640 & 390 \\
\hline Hard maple & 82,708 & 3,290 & 13,408 & 56,137 & 9,874 \\
\hline Soft maple & 360,054 & 26,766 & 87,307 & 202,591 & 43,390 \\
\hline Elm & 1,852 & - & 1,852 & - & - \\
\hline Black ash & 10,068 & - & - & 10,068 & . \\
\hline White \& green ash & 34,919 & 12,907 & 17,311 & 4,700 & - \\
\hline Balsam poplar & 13,458 & 2,883 & 4,308 & 6,267 & - \\
\hline Bigtooth aspen & 166,849 & 11,340 & 67,148 & 78,923 & 9,437 \\
\hline Quaking aspen & 101,317 & 1,545 & 29,162 & 63,483 & 7,127 \\
\hline Paper birch & 10,457 & - & 1,544 & 8,913 & - \\
\hline Black cherry & 42,965 & 5,652 & 7,127 & 26,331 & 3,855 \\
\hline Butternut & 1,000 & 132 & 166 & 613 & 90 \\
\hline Total hardwoods & $1,822,179$ & 199,957 & 522,612 & 873,619 & 225,992 \\
\hline
\end{tabular}


The United States Depantment of Agriculture (USDA) prohibıts discrimination in its programs on the basis of race, color, natıonal orıgin, sex, religıon, age, disability,

political beliets, and masital or tamilial status. (Not all prohibited bases apply to all programs.) Persons with disabilities who require altemative means of communication of program information (braille. large print, audiotape, etc.) should contact the USDA Office of Communications at (202) 720-2791.

To file a complaint, write the Secretary of Agriculture, U.S. Department of Agriculture. Washington, DC 20250, or call 1-800-245-6340 (voice). or 202-720-1127 (TDD). USDA is an equal employment opponunity employer 
Haugen, David; Ingram, Rosalie; Ruppert, Forrest.

1996. The forest resources of the Huron-Manistee National Forests, 1993. Resour. Bull. NC-181. St. Paul, MN: U.S. Department of Agriculture, Forest Service, North Central Forest Experiment Station. 40 p.

The inventory of the forest resources of the Huron-Manistee National Forests reports 964.9 thousand acres of land, of which 951.1 thousand acres are forested. This bulletin presents statistical highlights and contains detailed tables of forest area, timber volume, growth, removals, and mortality.

KEY WORDS: Forest area, timber volume, growth, removals, mortality. 
Our job at the North Central Forest Experiment Station is discovering and creating new knowledge and technology in the field of natural resources and conveying this information to the people who can use it. As a new generation of forests emerges in our region, managers are confronted with two unique challenges: (1) Dealing with the great diversity in composition, quality, and ownership of the forests, and (2) Reconciling the conflicting demands of the people who use them. Helping the forest manager meet these challenges while protecting the environment is what research at North Central is all about. 